Discussion Paper No. 16-082

\title{
The House Price-Vacancy Curve
}

Oliver Lerbs and Markus Teske

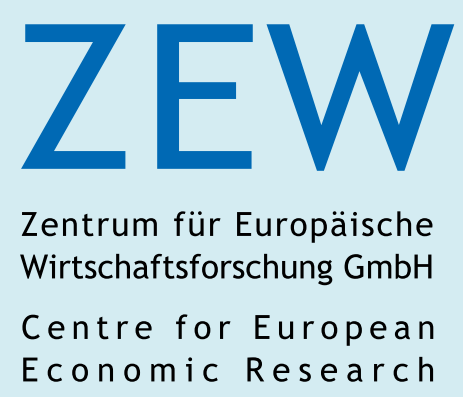


Discussion Paper No. 16-082

\title{
The House Price-Vacancy Curve
}

\author{
Oliver Lerbs and Markus Teske
}

Download this ZEW Discussion Paper from our ftp server:

http://ftp.zew.de/pub/zew-docs/dp/dp16082.pdf

Die Discussion Papers dienen einer möglichst schnellen Verbreitung von neueren Forschungsarbeiten des ZEW. Die Beiträge liegen in alleiniger Verantwortung der Autoren und stellen nicht notwendigerweise die Meinung des ZEW dar.

Discussion Papers are intended to make results of ZEW research promptly available to other economists in order to encourage discussion and suggestions for revisions. The authors are solely responsible for the contents which do not necessarily represent the opinion of the ZEW. 


\title{
The House Price-Vacancy Curve
}

\author{
Oliver Lerbs*, Markus Teske ${ }^{\dagger}$
}

This version: December 2016

\begin{abstract}
Individual sales prices and local vacancy rates in the housing market pose a natural analogy to the wage curve, a popular concept in labor economics that describes how individual wages decrease with higher local unemployment. While housing search and matching models and housing externalities strongly suggest a stable inverse relationship, there is still a lack of convincing empirical research on the sensitivity of house sales to local vacancy variation. Based on more than 10,000 single-family home transactions from the German market, this paper confirms a robust house price-vacancy curve among individual home prices and adjacent residential vacancies. The economic size of the relationship is highly comparable across all four analyzed states: a doubling of the vacancy rate at the municipality level is associated with a $5-8 \%$ discount in quality-controlled selling prices. Despite negative price signals, local vacancy distributions tend to persist over long time horizons, leaving room for policy intervention.
\end{abstract}

Key words: House prices, Housing vacancy, Hedonic regression, Wage curve JEL classification: R23, R31, R58

\footnotetext{
${ }^{*}$ Centre for European Economic Research (ZEW), Research Department International Finance and Financial Management, E-Mail: lerbs@zew.de

${ }^{\dagger}$ Centre for European Economic Research (ZEW), Research Department International Finance and Financial Management, E-Mail: teske@zew.de
} 


\section{Introduction}

Elevated vacancy rates in local housing markets pose a fundamental risk to private homeowners. Large inventories of vacant dwellings for sale or rent imply an affluent supply of housing that potential buyers consider as possible substitutes. ${ }^{1}$ This depresses the bargaining power of sellers and incentivizes them to accept lower offers more quickly (Hartley, 2014). Vacant homes not in active supply can depress selling prices of adjacent properties through negative externalities associated with negligence or vandalism (Rossi-Hansberg et al., 2010). Through both these channels, elevated vacancies in local housing markets increase individual resale risk, the virtually unhedgeable risk of not being able to sell a house at an adequate price within a sufficiently short marketing time (DiPasquale and Wheaton, 1996; Krainer, 2001). ${ }^{2}$ A negative link should consequently emerge between individual sales prices in an area and the corresponding local rate of vacancy.

While the theoretical arguments are appealing, it is a challenging task to pin down the exact relationship among individual house prices and local vacancy levels empirically. The present paper aims at filling this gap. Based on representative data on more than 10,000 individual single-family home (SFH) transactions from the German housing market, we provide microeconometric evidence in favor of a robust house price-vacancy curve that is largely invariant to geography. Based on exploiting small-scale heterogeneity in residential vacancy rates, we postulate that individual property prices and housing vacancies render a close analogy to the popular labor economics concept of the wage curve, which describes the negative link between individual workers' earnings and aggregate unemployment in the relevant labor market and has been coined by some an empirical law in economics (Blanchflower and Oswald, 1994; Nijkamp and Poot, 2005). ${ }^{3}$

There is a surprising lack of empirical research aimed at housing vacancies in general, and in particular at measuring the sensitivity of individual selling prices to local variation in vacancy. This can hardly be attributed to a lack of theory: some early influential research on housing market search and matching has strongly suggested a stable inverse relationship (Wheaton, 1990; Forgey et al., 1996). Piazzesi et al. (2015) recently extend the housing market matching litera-

\footnotetext{
${ }^{1}$ Piazzesi et al. (2015) document that housing search occurs predominantly among three dimensions: geography, price and, to a lesser extent, home size.

${ }^{2}$ Not all vacancy is necessarily associated with excess supply or negative externalities: some housing units are held vacant for seasonal use, while others are vacant only for short time periods in order to accomodate movers. Only a substantial rate of unintended, long-term vacancy signals a truly deficient allocation of economic resources. For a recent discussion of U.S. housing vacancies, see Molloy (2016).

${ }^{3}$ The wage curve is commonly interpreted as an equilibrium locus that reflects local differences in efficiency wages or bargaining power (Blanchflower and Oswald, 1994; Card, 1995; Blanchflower and Oswald, 2005). The empirically most supported relationship is one of constant elasticity, $\log (w)=\alpha+\beta \log (u)+$ other variables.
} 
ture by allowing for multiple market segments and heterogeneous searchers, still showing that prices and inventory covary negatively within submarkets. A possible explanation for the lack of comprehensive empirics is the lack of reliable data on vacancy at appropriately small spatial scales for wider geographical areas (especially nationwide). Much different from individual unemployment, residential vacancies are seldomly reported on a systematic basis. Very few data sets allow linking transaction prices with sufficiently disaggregated information on vacancy in the relevant housing (sub-)markets.

The present paper contributes to the literature in three main ways. First, we have access to a nationwide, complete count of non-seasonal, non-recreational vacant dwellings derived from an inventory of the German housing stock for the year of 2011. This enables us to investigate the effect of vacancies on nearby property prices for a much larger geographical area than previous studies. Second, this is one of the few attempts to investigate the relationship at hand outside of the U.S. To our knowledge, it is the first one to do so for Germany, the largest housing market in Europe. From observing very similar coefficients across the four analyzed German states, we thirdly motivate the novel concept of a house price-vacancy curve, which we interpret as symmetric case of the well-known wage curve in local labor markets. Our study provides a starting point for further research on this new concept.

We estimate that a doubling of the vacancy rate at the level of the local municipality is associated with an $8-12 \%$ decrease of individual single-family home selling prices. This price discount lies in an economically plausible range and holds across different states and specifications. The observed vacancy elasticity of individual home prices is strikingly close to the unemployment elasticity of individual wages, which is commonly measured at about -0.1 (Nijkamp and Poot, 2005). Among competing explanations for this downward-sloping house pricevacancy curve, we argue that increased sales time and lower seller reservation prices arising from increased competition are the most promising ones.

Our analysis carefully takes account of potential coefficient bias related to omitted variables or reverse causality. It is reasonable to assume that many factors that influence individual home selling prices are also correlated with the local rate of vacancy. Ignoring those factors would result in biased estimation of the true relationship between the vacancy rate and sales prices. We therefore control for a broad range of property- and neighborhood-level characteristics in hedonic pricing models. Since homeowners may moreover be prone to leave their house vacant just when house prices in the neighborhood are low, we employ instrumental variable regression in order to address this potential issue of reverse causality.

The remainder of the paper is organised as follows: Section 2 serves to motivate the case of a downward-sloping house price-vacancy curve, focusing on two 
major channels: competition and negative externalities. Section 3 presents and discusses the data set used to identify price-vacancy curves. Section 4 discusses the hedonic pricing equations, including a discussion of functional form. State-bystate econometric results are provided in Section 5, including robustness checks on variable selection and endogeneity. In view of a robust result of negative price effects arising from higher local vacancies, Section 6 discusses the extent to which these discounts drive local housing markets back to equilibrium in the long run, making use of historical data on small-scale vacancy rate distributions. Section 7 concludes and discusses potential limitations and policy implications.

\section{Motivating a House Price-Vacancy Curve}

\subsection{Competition}

A first channel through which vacant dwellings are expected to negatively affect nearby house prices is increased competition for buyers. Wheaton (1990) proposes a stylized search and matching model that rationalizes systematic links between vacancy, expected sales time and selling prices in the housing market. The model is inspired by the labor economics workhorse models of Diamond (1982), Mortensen (1982) and Pissarides (1990) and treats vacancy and prices as equilibrium outcomes in an environment of uncertainty and bargaining. ${ }^{4}$ The steady-state solution of the model states that the reservation price of optimizing seller-buyers ${ }^{5}$ - the marginal price at which a randomly arriving offer is to be accepted - is inversely proportional to expected sales time and the costs of holding two units at a time. Since a larger inventory of vacant units in the relevant market increases expected sales time for each individual seller in the market, higher vacancies result in lower selling prices in the short- as well as in the long-run. ${ }^{6}$

A downside feature of the theoretical model by Wheaton (1990) is its prediction of an extreme sensitivity of selling prices with regard to expected marketing time, which is in turn inversely proportional to vacancy. In the calibration of his model, a doubling of the vacancy rate induces very strong price declines of as much as 50 per cent. The reason for this unrealistically large sensitivity is that buyers in his model are unconstrained: since buyers are also sellers, there is no market entry or exit, which renders demand highly inelastic with regard to price.

\footnotetext{
${ }^{4}$ Williams (1995) generalizes Wheaton's model to a continuous time setting and shows that many of the comparative statics from this model are also valid in a dynamic setting.

${ }^{5}$ Different from labor markets, where personal unemployment spells occur even with voluntary job changes, mobility in housing markets generally involves spells in which households own or rent two units. In this case, mobile households become buyers and sellers at the same time.

${ }^{6}$ Based on the idea of search and matching, it can be argued that there must be an optimal (or „natural“) rate of vacancy. In analogy to the natural rate of unemployment, Rosen and Smith (1983) and Gabriel and Nothaft (2001) define it as the rate of vacancy at which housing prices are (dynamically) stable. No concensus has yet been reached on the level of optimal vacancy, which is likely to highly depend on market context.
} 
It is unlikely to observe such large sensitivity of prices with regard to vacancy in reality for at least two reasons: first, market entries and exits potentially account for a very substantial part of transactions. In this case, buyers are not necessarily sellers in the same market, which allows demand to be much more elastic with respect to price. Second, moving households residing in high-vacancy, „illiquid“ areas might accept a longer sales time and price their house high enough to avoid nominal losses or to fish for a downpayment on the next house. This behavioral argument was first brought forward by Stein (1995) and has found strong empirical support by Genesove and Mayer (2001).

Krainer (2001) integrates the loss aversion argument into a matching model where selling prices, expected sales time and sales volume depend simultaneously on buyers' state-varying valuations of housing services. Shocks to the fundamental value of housing in this model are not solely transmitted through changes in selling prices: when prices are sticky in that they do not drop too strongly in weak markets, there also must be a transmission through a change in sales time. In times of high valuations of housing services, sellers price properties in a way that ensures swift transactions: they avoid being forced to sell in times of lower buyer valuations. When buyers' valuations of housing services are low instead, sellers accept longer sales times instead of transacting at prices that would ensure the same amount of liquidity, which results in lower sales volumes and higher inventory. High vacancy rates in „cold“ markets go along with relatively low prices, and vice versa.

Genesove and Han (2012) empirically test these key predictions of housing market matching models. While not explicitly focusing on vacancy, they investigate the effect of demand shocks on average sales time (inversely related to vacancy) and the number of homes that buyers visit. Based on survey data of homebuyers conducted by the National Association of Realtors combined with data on demand shocks at the level of U.S. MSAs, they provide evidence that with rising demand, time on the market decreases for both buyers and sellers, but more strongly so for sellers. This result confirms that the probability of a match increases with demand. The increase in probability drives prices up, while simultaneously reducing average sales time and housing vacancy.

A recent paper by Piazzesi et al. (2015) advances the theoretical literature on housing market search, vacancy and prices by studying housing markets with multiple segments searched by heterogeneous clienteles. Their approach differs from existing models of housing search in the assumption that searchers are inhomogeneous, which implies that a housing market can be partitioned into heteregeneous submarkets. Their model is able to match the empirical fact that search activity, turnover and inventory typically covary positively within local housing markets, but negatively across those units. In particular, individual houses are cheaper in areas or segments where houses take long times to sell due to many alternatives 
(more inventory), which Piazzesi et al. (2015) call a „liquidity discount“. Liquidity discounts can differ widely across segments, even within the same narrow geographic area.

\section{$2.2 \quad$ Negative externalities}

A second channel through which vacant dwellings are expected to affect nearby house prices is adverse spillover effects. House values are known to be highly dependent on buyers' perceived quality of location, which is strongly related to the physical condition and appearance of neighboring homes. Leaving homes vacant is a primary example of a "housing externality“ as coined by Rossi-Hansberg et al. (2010): the social costs associated with vacancy-related negligence or vandalism are not incorporated in property owners' decisions. ${ }^{7}$ Based on detailed data on the Neighborhoods-in-Bloom urban revitalization program in Richmond, Virginia, Rossi-Hansberg et al. (2010) show that demolition, rehabilitation and reconstruction of vacant homes had strong positive effects on land values in impact areas compared to otherwise comparable control neighborhoods. ${ }^{8}$ These externalities tend to be extremely spatially concentrated, declining by half about every 1000 feet.

As a response to the U.S. subprime mortgage crisis, much recent research has investigated spillover effects from foreclosures on nearby house prices. Exploiting exogenous variation in U.S. state judicial foreclosure requirements, Mian et al. (2015) find a large negative impact of foreclosures on nearby house prices and suggest that through consequent drops in consumption and investment, the spike in foreclosures was an important factor in the length and depth of the great recession. Gerardi et al. (2015) and Ihlanfeldt and Mayock (2016) also provide evidence for negative effects of nearby foreclosures on single-family home prices. Lin et al. (2009) and Campbell et al. (2011) demonstrate that price discounts strongly increase with closer proximity to foreclosed properties. It is however important to note that foreclosures do not automatically overlap with vacancies, and only a limited number of studies disentangles negative spillover effects of foreclosures from increased competition through more available housing supply. Anenberg and Kung (2014) and Hartley (2014) attempt to decompose the price effect of foreclosures into a competition and a disamenity component. They both find that the spillover component is near zero for most analyzed areas, which suggests a dominance of the competition channel.

One of the very few papers focusing explicitly on vacant dwellings is Whitaker and Fitzpatrick (2013). This study links vacancy observations from U.S. Postal

\footnotetext{
${ }^{7}$ The strategic situation of individual homeowners in a high-vacany housing (sub-)market resembles the classic prisoners' dilemma Nash-equilbrium, in which the socially optimal result of demolishing excess housing in order to stabilise individual house prices is not achieved.

${ }^{8}$ Neighborhoods to be revitalized were selected with regard to multiple criteria, including the stock of vacant houses.
} 
Service data with property-tax delinquency and housing sales data from Cuyahoga County, Ohio, between 2010-2011. Distressed homes, which are defined as either tax-delinquent, foreclosed, or vacant, all have negative effects on selling prices of nearby single-family homes. Concerning the separate effect of vacancy, any additional vacant house within a 500 feet radius reduces selling prices by about $1 \%$ in low-poverty census tracts, whereas no such effect is found in highpoverty census tracts. Price discounts get larger if vacant homes are also taxdelinquent, which the authors associate with property neglect. Compared to the prior findings, the quantitative effect of vacancy is small, which suggests that jointly estimating the effect of foreclosure, vacancy and tax-delinquency overstates the separate impact of each.

\section{Data}

We analyse large cross-sections of individual SFH transactions completed between January 1 and December 30, 2011 in four different German states. Our sample covers the states of Brandenburg (BB) and Saxony-Anhalt (SA) as two eastern (former German Democratic Republic) states, as well as Lower Saxony (LS) and Rhineland-Palatinate (RP) as two western states. All transaction data are obtained from the Superior Committees of Valuation Experts (Obere Gutachterausschüsse in German) of the corresponding states, public agencies that maintain registers on the entire universe of property sales in the specific state. ${ }^{9}$ The transaction data are detailed and highly representative, which makes our results applicable to the whole SFH stock: we have access to a 26 percent random sample of the entire population of SFH transactions in 2011 for Lower Saxony, and the total population of all transactions for the other three states. In total, our sample covers 10,689 individual sales, including transacted properties' characteristics.

We match the individual transaction data to small-scale spatial data on vacancies and structural variables capturing cross-sectional differences in sociodemographic and economic conditions among localities. Matching occurs at the level of municipalities, which typically range between U.S. Census Block Groups and Census Tracts in terms of population size. ${ }^{10}$ We obtain data on vacancies from a complete inventory of the German housing stock compiled within the 2011 Census, which encompassed a count of non-seasonal, non-recreational vacant housing units. ${ }^{11}$ A housing unit is considered vacant if it was neither

\footnotetext{
${ }^{9}$ Individual property transaction data in Germany are collected decentrally and still in a heterogeneous way. So far, all but one German states have established a central register of property sales. However, this was mostly not the case in 2011 . We are therefore limited in our analysis to four states.

${ }^{10}$ Table A1 in the appendix provides detailed information on data definitions and sources.

${ }^{11}$ We only take into account vacancies in residential buildings, excluding hostels and nursing homes as well as dwellings of diplomats and foreign armed forces. Vacancies occuring in buildings for commercial use are not included.
} 
owner-occupied nor rented out on the Census reference day, excluding units temporarily not inhabitated due to modernization or renovation. ${ }^{12}$ Using the overall number of residential dwellings minus holiday homes in each locality as the denominator, we compute very accurate, fine-grained data on local vacancy rates allowing for a proper identification of a house price-vacancy relationship. The municipal vacancy data covers the entire geography of all four analyzed states.

The vacancy rate variation across municipalities for which we observe SFH transactions ${ }^{13}$ is substantial, ranging from $0 \%$ in several municipalities in Brandenburg, Lower Saxony and Rhineland-Palatinate to over $20 \%$ in some municipalities in Lower Saxony and Saxony-Anhalt. The average vacancy rate of municipalities with SFH transactions in the dataset is 5.6\% in Brandenburg, 3.9\% in Lower Saxony, $4.7 \%$ in Rhineland-Palatinate and $8.2 \%$ in Saxony-Anhalt. Figure 1 groups median house prices into thirty local vacancy rate bins, providing a first rough glance at price-vacancy-relationships in each state.

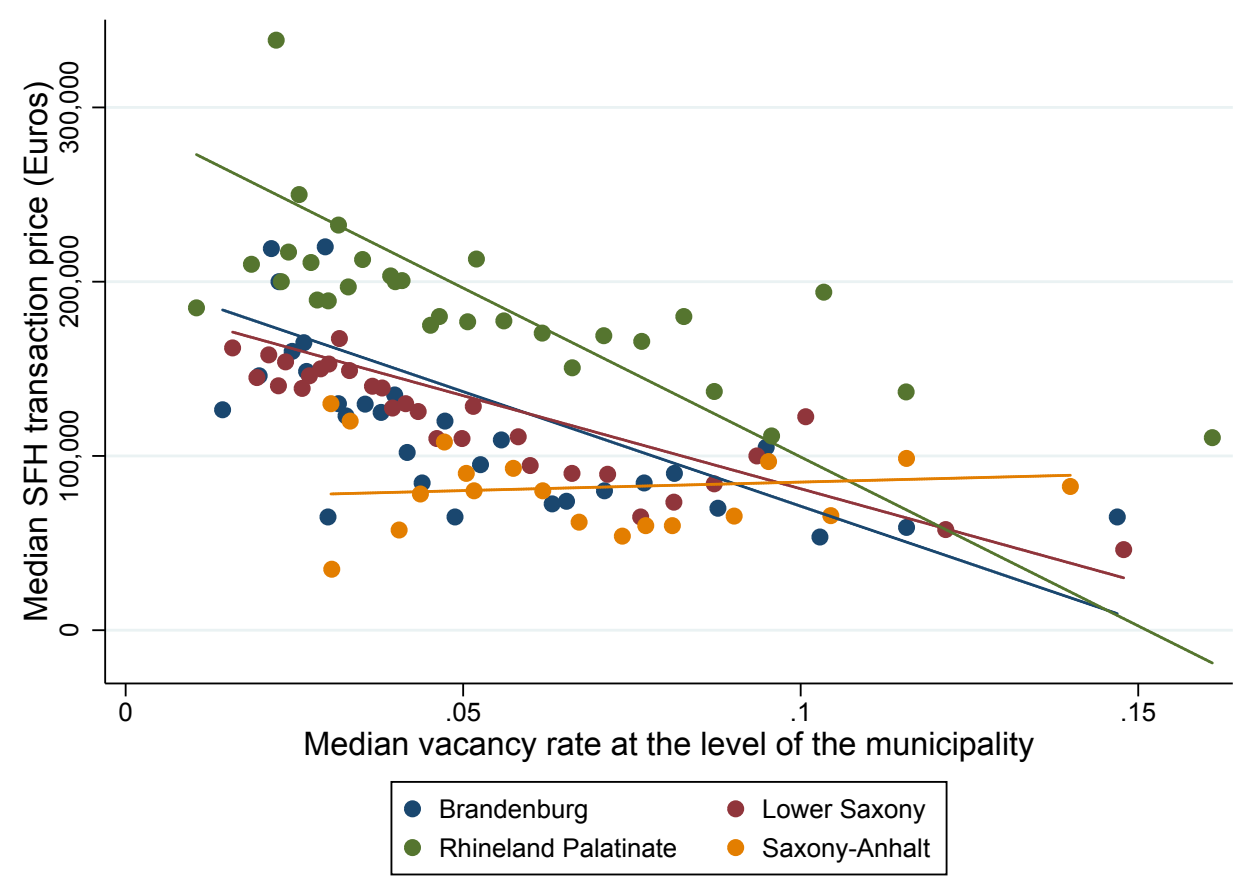

Figure 1: Median of vacancy rates and median home prices for 30 bins in four states (Brandenburg, Lower Saxony, Rhineland-Palatinate and Saxony-Anhalt).

\subsection{Property characteristics}

The number of recorded property characteristics differs by state. The following are available for all four: building type (detached house, semi-detached house,

\footnotetext{
${ }^{12}$ Unfortunately, cause and temporal duration of vacancy were not reported in the 2011 German Census.

${ }^{13} 312$ municipalities in Brandenburg, 609 in Lower Saxony, 455 in Rhineland-Palatinate and 197 in Saxony-Anhalt.
} 
row house or row house end unit) $)^{14}$, lot size, floor space, year of construction, land value of the lot, and the date of sale. For most transactions in Lower Saxony and Saxony-Anhalt, we additionally have access to an ordinal indicator of the quality of equipment. Further information available for some properties includes the type of heating, existence of a cellar or garage, roof type, and further physical characteristics.

Since the rate of vacancy is expected to strongly correlate with local location quality, controlling for the quality of location is of utmost importance in our analysis. For privacy protection reasons, we unfortunately cannot obtain information on the exact geocoordinates of the properties, which prior research uses to construct an index of location quality at the micro (property) level. We do have information however on each individual property's publicly registered land value (Bodenrichtwert in German). The land value refers to the assessed monetary value of the lot apart from the value of structures. ${ }^{15}$ Land value assessment in Germany is conducted on an annual basis by the Local Committees of Valuation Experts. ${ }^{16}$ By including property-level land values in the hedonics, we can directly control for a large battery of latent locational factors, such as the accessibility of public transport and other amenities/disamenities.

Summary statistics for the main property characteristics are displayed in Table 1. Median home sales prices range from 75,000 Euros in Saxony-Anhalt to 189,000 Euros in Rhineland-Palatinate. Detached houses account for the majority of transactions in all four states, with shares ranging from $54 \%$ in RhinelandPalatinate and Saxony-Anhalt to $69 \%$ in Lower Saxony. Average living space ranges from 115 (Saxony-Anhalt) to 142 square metres (Rhineland-Palatinate), while average lot size ranges from slightly above 500 square metres (RhinelandPalatinate) to about 850 square metres (Brandenburg). Average building age is lowest in Lower Saxony with 39 years and highest in Saxony-Anhalt with 70 years. The average land value in the data set ranges from 34 Euros per square metre in Saxony-Anhalt to 172 Euros per square metre in Rhineland-Palatinate, indicating substantial variation in average location quality across states.

\footnotetext{
${ }^{14}$ In Rhineland-Palatinate, a fifth property type „individual construction“ is reported for properties that cannot be clearly assigned to one of the four other categories.

${ }^{15}$ For the U.S. case, Cohen et al. (2015) employ local polynonomial regressions to separate land values from structure values, which encompasses the estimation of hedonic models.

${ }^{16} \mathrm{~A}$ variety of characteristics is taken into account, most importantly the quality of location of the property: a longer distance to a city center, for example, decreases the land value. The assessment is based on comparable market transactions and usually extends to several lots. For areas without a sufficient number of comparables, which is typical for rural areas, the Valuation Experts resort to subjective assessments.
} 


\begin{tabular}{|c|c|c|c|c|c|c|c|c|c|c|c|c|c|c|c|c|}
\hline \multirow{2}{*}{$\frac{\text { State }}{\text { Variable }}$} & \multicolumn{4}{|c|}{ BB } & \multicolumn{4}{|c|}{ LS } & \multicolumn{4}{|c|}{$\mathrm{RP}$} & \multicolumn{4}{|c|}{$\mathrm{SA}$} \\
\hline & Mean & Median & Minimum & Maximum & Mean & Median & Minimum & Maximum & Mean & Median & Minimum & Maximum & Mean & Median & Minimum & Maximum \\
\hline \multicolumn{17}{|l|}{ Property characteristics } \\
\hline Transaction price (k Euro) & 140.213 & 125.000 & 3.000 & $1,800.000$ & 148.752 & 137.750 & 15.000 & $1,200.000$ & 207.314 & 189.000 & 10.000 & 845.000 & 83.915 & 75.000 & 1.000 & 410.000 \\
\hline Lot size $\left(\mathrm{m}^{2}\right)$ & 858 & 748 & 61 & 8617 & 775 & 675 & 50 & 9,333 & 517 & 434 & 40 & 5,992 & 714 & 600 & 50 & 4140 \\
\hline Living space $\left(\mathrm{m}^{2}\right)$ & 118 & 115 & 30 & 505 & 136 & 128 & 50 & 450 & 142 & 136 & 3 & 1,675 & 115 & 110 & 28 & 423 \\
\hline Age (years) & 46 & 33 & 0 & 311 & 39 & 38 & 0 & 161 & 47 & 41 & 0 & 511 & 70 & 72 & 0 & 475 \\
\hline Semi-detached house (dummy) & 0.21 & - & 0 & 1 & 0.14 & - & 0 & 1 & 0.14 & - & 0 & 1 & 0.27 & - & 0 & 1 \\
\hline Detached house (dummy) & 0.68 & - & 0 & 1 & 0.69 & - & 0 & 1 & 0.54 & - & 0 & 1 & 0.54 & - & 0 & 1 \\
\hline Row house end unit (dummy) & 0.05 & - & 0 & 1 & 0.06 & - & 0 & 1 & 0.08 & & 0 & 1 & 0.08 & - & 0 & 1 \\
\hline Row house (dummy) & 0.06 & - & 0 & 1 & 0.11 & - & 0 & 1 & 0.18 & - & 0 & 1 & 0.11 & - & 0 & 1 \\
\hline Individual construction (dummy) & - & - & - & - & - & - & - & - & 0.06 & - & 0 & 1 & - & - & - & - \\
\hline Land value (Euro per m²) & 59.86 & 49 & 0 & 400 & 86.16 & 75 & 0 & 550 & 171.81 & 170 & 0.60 & 705 & 33.82 & 25 & 5 & 180 \\
\hline \multicolumn{17}{|l|}{ Municipality characteristics } \\
\hline Vacancy rate & 0.056 & 0.052 & 0 & 0.200 & 0.039 & 0.033 & 0 & 0.245 & 0.047 & 0.045 & 0 & 0.179 & 0.082 & 0.079 & 0.030 & 0.233 \\
\hline Inhabitants (thousands) & 7.510 & 3.268 & 0.382 & 156.021 & 11.801 & 5.609 & 0.316 & 506.416 & 5.417 & 1.637 & 0.027 & 200.344 & 11.450 & 7.280 & 0.845 & 229.153 \\
\hline Population density (k of inhabitants per $\mathrm{km}^{2}$ ) & 0.143 & 0.047 & 0.008 & 2.300 & 0.181 & 0.122 & 0.017 & 2.485 & 0.252 & 0.179 & 0.016 & 2.054 & 0.118 & 0.075 & 0.013 & 1.691 \\
\hline Per capita income (k of Euro) & 10.760 & 10.020 & 6.727 & 25.210 & 14.062 & 13.792 & 8.342 & 29.138 & 15.270 & 14.722 & 4.772 & 66.462 & 10.175 & 9.952 & 7.033 & 16.307 \\
\hline Ratio SFH of total dwellings & 0.53 & 0.56 & 0.11 & 0.82 & 0.53 & 0.55 & 0.12 & 0.84 & 0.54 & 0.56 & 0.16 & 0.94 & 0.47 & 0.50 & 0.09 & 0.75 \\
\hline Local property tax leverage factor & 3.58 & 3.60 & 2.50 & 4.93 & 3.58 & 3.50 & 2.50 & 5.30 & 3.41 & 3.40 & 0.80 & 5.00 & 3.56 & 3.56 & 2.50 & 4.75 \\
\hline Local public spending per inhabitant (k Euro) & - & - & - & - & 1.186 & 1.045 & 0.650 & 12.221 & 0.996 & 0.910 & 0.036 & 5.205 & - & - & - & - \\
\hline Very central (dummy) & 0.06 & - & 0 & 1 & 0.03 & - & 0 & 1 & 0.26 & - & 0 & 1 & 0.01 & - & 0 & 1 \\
\hline Central (dummy) & 0.14 & - & 0 & 1 & 0.39 & - & 0 & 1 & 0.41 & - & 0 & 1 & 0.11 & - & 0 & 1 \\
\hline Peripheral (dummy) & 0.28 & - & 0 & 1 & 0.48 & - & 0 & 1 & 0.27 & - & 0 & 1 & 0.71 & - & 0 & 1 \\
\hline Very peripheral (dummy) & 0.52 & - & 0 & 1 & 0.10 & - & 0 & 1 & 0.06 & - & 0 & 1 & 0.17 & - & 0 & 1 \\
\hline Mostly urban (dummy) & 0.13 & - & 0 & 1 & 0.17 & - & 0 & 1 & 0.34 & - & 0 & 1 & 0.10 & - & 0 & 1 \\
\hline Partly urban (dummy) & 0.11 & - & 0 & 1 & 0.31 & - & 0 & 1 & 0.36 & - & 0 & 1 & 0.24 & - & 0 & 1 \\
\hline Rural (dummy) & 0.76 & - & 0 & 1 & 0.52 & - & 0 & 1 & 0.30 & - & 0 & 1 & 0.66 & - & 0 & 1 \\
\hline Strongly growing (dummy) & 0.11 & - & 0 & 1 & 0.15 & - & 0 & 1 & 0.13 & - & 0 & 1 & 0.01 & - & 0 & 1 \\
\hline Growing (dummy) & 0.16 & - & 0 & 1 & 0.31 & - & 0 & 1 & 0.15 & - & 0 & 1 & 0.01 & - & 0 & 1 \\
\hline Stable (dummy) & 0.01 & - & 0 & 1 & 0.16 & - & 0 & 1 & 0.16 & - & 0 & 1 & 0.01 & - & 0 & 1 \\
\hline Shrinking (dummy) & 0.21 & - & 0 & 1 & 0.28 & - & 0 & 1 & 0.51 & - & 0 & 1 & 0.12 & - & 0 & 1 \\
\hline Severely shrinking (dummy) & 0.51 & - & 0 & 1 & 0.10 & - & 0 & 1 & 0.05 & - & 0 & 1 & 0.85 & - & 0 & 1 \\
\hline
\end{tabular}

Table 1: Summary statistics on property characteristics and municipal variables. Lot size for BB is winsorized for one extreme value. Price for RP is winsorized for one extreme value. Living space for RP is winsorized for three extreme values. Lot size for SA is winsorized for one extreme value. Building age is winsorized for SA for 28 extreme values. 


\subsection{Locational characteristics}

We match our sales data with sociodemographic and economic information at the municipality level from various sources. In addition to the residential vacancy rate, we obtain from the 2011 Census the total size of local population and population density. As a measure of local purchasing power, we use data on the average taxable income per local resident from federal income tax statistics. In order to account for a potential confounding role of local variation in fiscal environments, we collect data on local property tax leverage factors for developed $\operatorname{land}^{17}$, as well as on local public spending per capita. Data on local property tax leverage factors is obtained from property tax statistics, whereas data on public spending comes from municipal budget statistics. In order to account for structural differences between locations, we finally collect data on the spatial centrality, the settlement type and the long-term growth performance of each municipality from the Federal Institute for Research on Building, Urban Affairs and Spatial Development (BBSR). ${ }^{18}$

A quick glance at Table 1 shows that the four analyzed states differ considerably with regard to local market characteristics. Mean population density and per capita income are considerably higher in the two western German states. Two thirds of all municipalities in Rhineland-Palatinate are classified as central or very central, whereas the corresponding shares in the three other states range from $12 \%$ in Saxony-Anhalt to $42 \%$ in Lower Saxony, indicating much larger proportions of peripheral municipalities. Another important difference relates to municipalities' long-term demographic and socio-economic development: Lower Saxony is the only state for which the number of growing or stable locations outranks that of shrinking ones in terms of total population, young-adult population, employment and public revenues. Even as much as $97 \%$ of municipalities in Saxony-Anhalt are shrinking or severely shrinking (Brandenburg: 72\%, Rhineland-Palatinate: $56 \%$ ). These large structural differences make us confident that our main results hold in very different market contexts.

Municipalities also differ between states in average size. About two thirds of all municipalities in Rhineland-Palatinate are very small, having less than 400 housing units. In Brandenburg, Lower Saxony and Saxony-Anhalt, the size distribution is somewhat more even, with the largest proportion of municipalities comprising less than 600 housing units (with relatively high proportions of larger municipalities). ${ }^{19}$

Figures 2-5 illustrate the geographic distributions of vacancy rates and the total number of SFH transactions observed in each municipality for all four states, with circle sizes being proportional to the number of sales:

\footnotetext{
${ }^{17}$ Grundsteuer $B$ in German.

${ }^{18}$ Table A1 in the appendix describes these three variables in more detail.

${ }^{19}$ See Figures A1-A4 in the appendix for histograms of municipality size.
} 


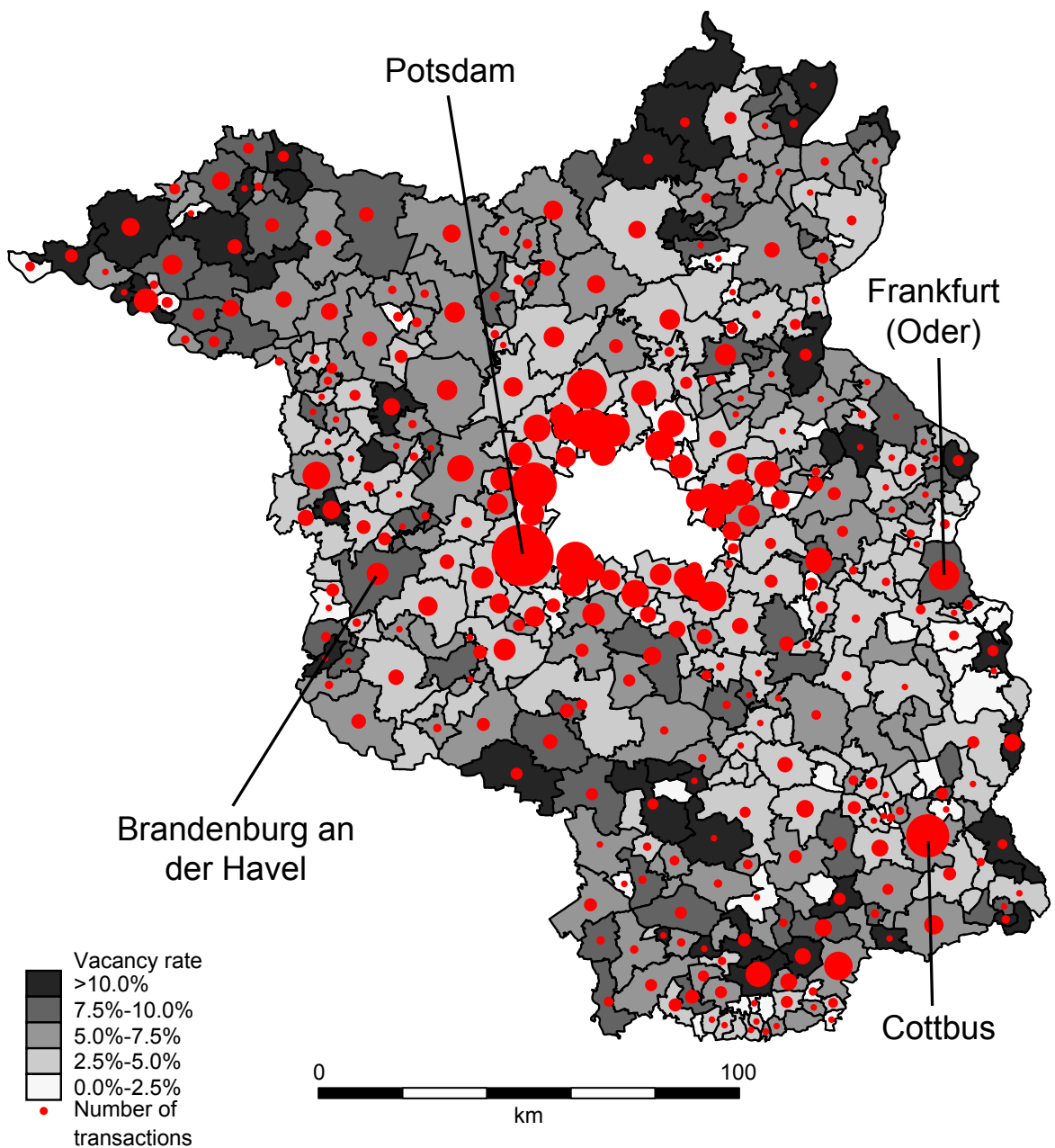

Figure 2: Spatial distribution of vacancy rates and SFH transactions in municipalities in Brandenburg in 2011. Transactions are recorded in 312 of 419 municipalities. 


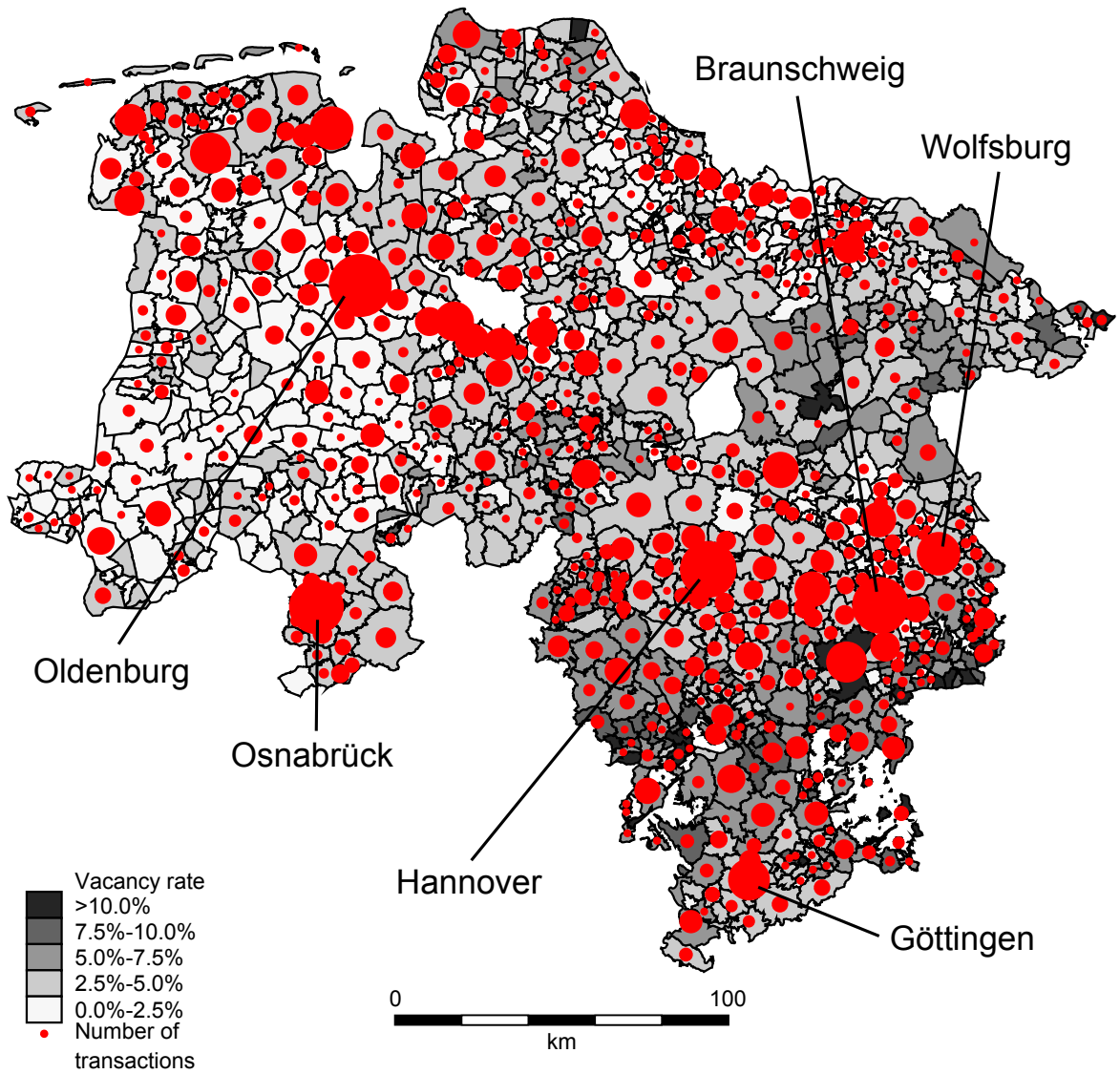

Figure 3: Spatial distribution of vacancy rates and SFH transactions in municipalities in Lower Saxony in 2011. Transactions are recorded in 609 of 1,008 municipalities. 


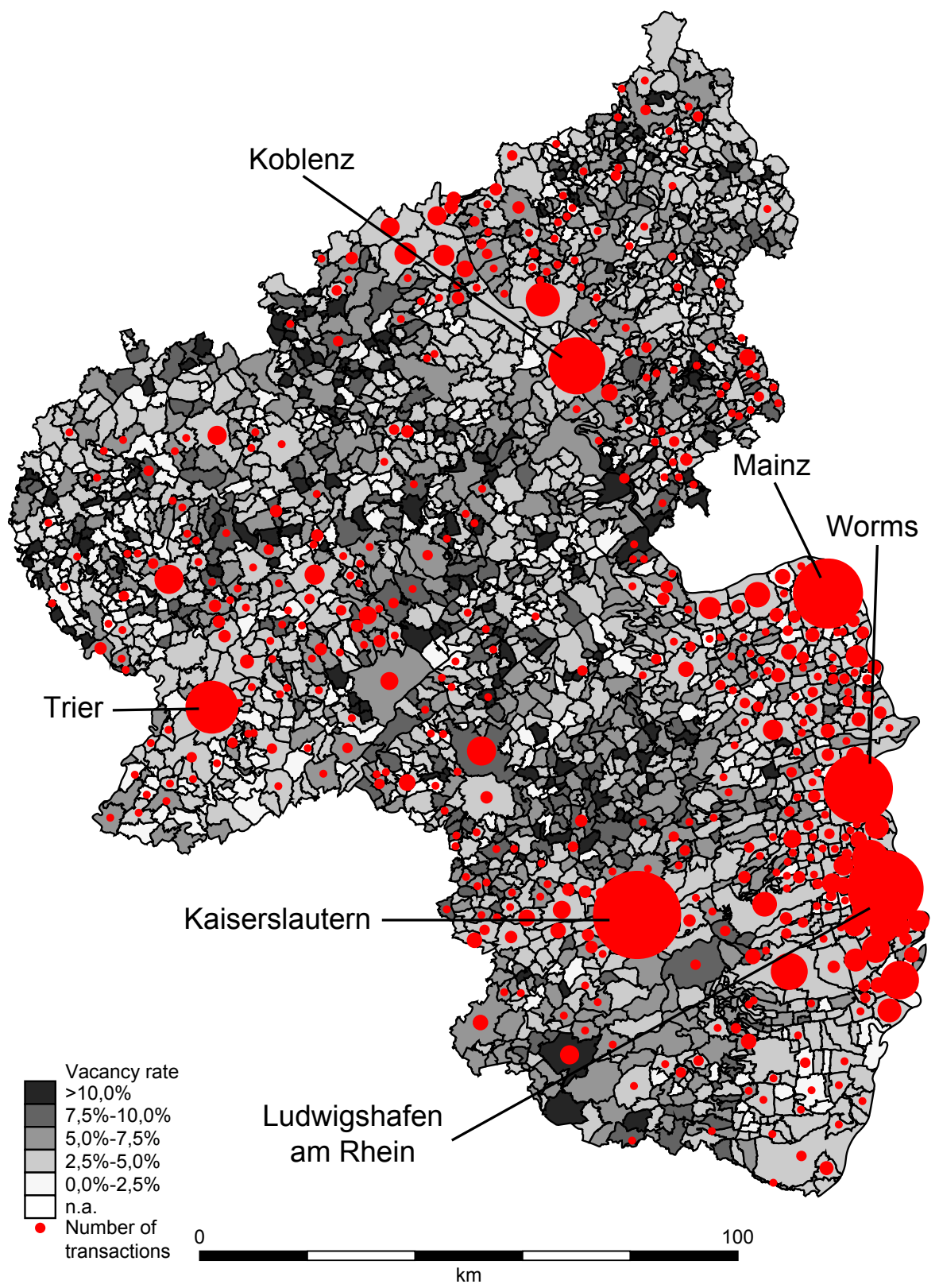

Figure 4: Spatial distribution of vacancy rates and SFH transactions in municipalities in Rhineland-Palatinate in 2011. Transactions are recorded in 455 of 2,306 municipalities. 


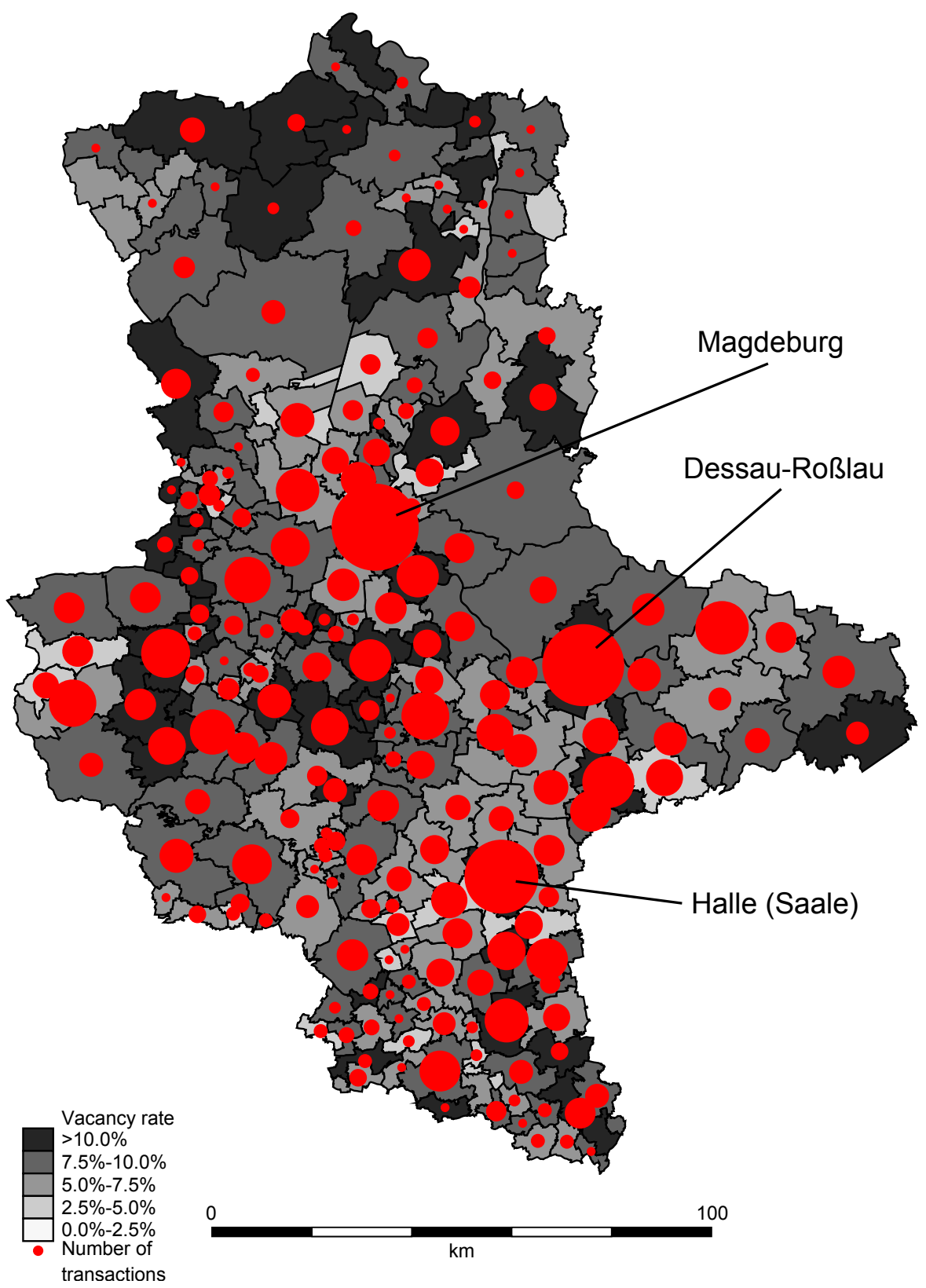

Figure 5: Spatial distribution of vacancy rates and SFH transactions in municipalities in SaxonyAnhalt in 2011. Transactions are recorded in 197 of 219 municipalities. 


\section{Identification}

We aim at identifying a monotonous home price-vacancy relationship by employing standard hedonic house price regressions (Rosen, 1974; Sheppard, 1999). We estimate:

$$
\begin{array}{r}
\log \left(p_{i, m}\right)=\alpha+\sum_{j=1}^{J} \beta_{j} x_{j i}+\gamma \log \left(v_{m}\right)+\sum_{k=1}^{K} \delta_{k} z_{k i, m}+u_{i, m} \\
u_{i, m} \sim \mathcal{N}\left(0, \sigma_{\epsilon}\right)
\end{array}
$$

where $p_{i, m}$ denotes the selling price of property $i$ in municipality $m, x_{j i}$ is a $j$-dimensional vector comprising property attributes, $v_{m}$ is the vacancy rate in municipality $m$ and $z_{k i, m}$ reflects municipality-level controls. ${ }^{20}$ We assume heteroscedastic random disturbances. Due to the two-layered structure of our dataset, we cluster standard errors at the municipality level to take account of error correlation within groups (Moulton, 1990; Wooldridge, 2010). Our main interest pertains to:

$$
\gamma=\frac{\partial \log \left(p_{i, m}\right)}{\partial \log \left(v_{m}\right)}=\frac{\partial p_{i, m}}{\partial v_{m}} \cdot \frac{v_{m}}{p_{i, m}},
$$

the sample mean elasticity of sales prices with respect to the municipal vacancy rate conditional on the included covariates. The respective samples are large enough to allow estimation of Equation (1) separately by state.

Our ultimate goal is to establish causality regarding the effect of higher local vacancy rates on $\mathrm{SFH}$ prices. We thus need to carefully address the questions of omitted variables and potential endogeneity of vacancy. In addition to extensively controlling for physical property characteristics, we rigorously control for location-quality differences by including the property-specific assessed land values and the municipality-specific indicators of centrality, settlement structure and long-term demographic and economic prospects. Endogeneity could arise from reverse causality: the observation of low market values may incentivize owners to leave their homes vacant. Potential resulting bias can be resolved by instrumental variables estimation. After discussing results of the baseline model in Subsection 5.1 , we address the problem of endogeneity among other checks for robustness in Subsection 5.2.

\footnotetext{
${ }^{20}$ Given ample empirical evidence that seasonality affects the residential real estate markets in the U.K. and the U.S. (Ngai and Tenreyro, 2014), we experimented with dummy variables indicating the quarter of the transaction date. As we did not find any significant partial effect of seasonality on selling prices in our sample for any state, we do not include time dummies in the specification. Results including quarter dummies are available upon request.
} 


\section{$5 \quad$ Econometric Results}

\subsection{Baseline Model}

Results of state-by-state estimations of Equation (1) are displayed in Table 2. All continuous right-hand side variables are mean-centered. Due to the differing number of property characteristics included in each state-specific regression beyond the common basic variables, we do not list the coefficients of all attributes but only report coefficients for the basic set of property-level controls for which we have information in each state. We winsorized some variables to account for the influence of extreme values. ${ }^{21}$

Goodness of fit for the baseline specifications is satisfactory: adjusted $R^{2}$ values range from 0.65 in Rhineland-Palatinate to 0.74 in Lower Saxony, indicating that only a minor share of variation in selling prices remains unexplained. Most importantly, strongly significant inverse relationships between individual selling prices and local vacancy rates are found for all states, as suggested by theory (for Saxony-Anhalt, the effect is barely significant at the 10\%-level). According to the estimates, a doubling of the vacancy rate in a municipality implies an average decrease in quality-controlled sales prices of $5-8 \%$, dependent on state. ${ }^{22}$ These estimates amount to considerable economic effects: at the state-specific mean local vacancy rate, a doubling of vacancy implies a 9,700 euros sales price discount for a typical (average-priced) home in Brandenburg, 10,400 euros in Lower Saxony, 15,000 euros in Rhineland-Palatinate and 5,900 euros in SaxonyAnhalt. Largely invariant to geography, the resulting percentage elasticity of sales prices to local vacancy is close to -0.1 - strikingly mimicking the well-known elasticity of individual workers' wages to aggregate local unemployment in labor markets.

Concerning statistical control, the coefficients estimated on property characteristics are generally significant and carry plausible signs. Semi-detached houses, row houses and homes of individual construction type tend to sell at lower prices than otherwise comparable detached houses, particularly so for row houses. Bigger lot sizes and more living space have the expected positive effects on sales prices. Consistent with existing research on housing price hedonics, the relation between selling price and age is U-shaped according to our estimates, indicating a vintage effect in home values. ${ }^{23}$ Higher assessed land values, which reflect

\footnotetext{
${ }^{21}$ Full results, including coefficients on all property characteristics for Brandenburg, Lower Saxony and Saxony-Anhalt, are listed in Table A2 in the appendix.

${ }^{22}$ In a strict sense, the logarithm with base two would be a more exact way to determine the effect of a doubling of the vacancy rate. In order to make our results directly comparable to the wage curve literature, we stick to the conventional log-log specification using natural logarithms and approximate the effect of a doubling in the vacancy rate by multiplying the reported coefficients by 0.6931 , which is the difference between the natural logarithm of a number and the natural logarithm of the number's double value.

${ }^{23}$ The turning points for the baseline models are very large, however: 140 years in BB, 120
} 


\begin{tabular}{|c|c|c|c|c|}
\hline State & $\mathrm{BB}$ & LS & $\mathrm{RP}$ & SA \\
\hline \multicolumn{5}{|l|}{ Variable } \\
\hline \multirow[t]{2}{*}{ Lot size $\left(\mathrm{m}^{2}\right)$} & $0.000017^{*}$ & $0.000123^{* * *}$ & $0.000194^{* * *}$ & $0.000209^{* * *}$ \\
\hline & $(0.000009)$ & $(0.000025)$ & $(0.000045)$ & $(0.000028)$ \\
\hline \multirow[t]{2}{*}{ Living space $\left(\mathrm{m}^{2}\right)$} & $0.005972^{* * *}$ & $0.002793^{* * *}$ & $0.003535^{* * *}$ & $0.004041 * * *$ \\
\hline & $(0.000273)$ & $(0.000194)$ & $(0.000279)$ & $(0.000591)$ \\
\hline \multirow[t]{2}{*}{ Age (years) } & $-0.007538^{* * *}$ & $-0.009336^{* * *}$ & $-0.006505^{* * *}$ & $-0.004885^{* * *}$ \\
\hline & $(0.000416)$ & $(0.000636)$ & $(0.000440)$ & $(0.000286)$ \\
\hline \multirow[t]{2}{*}{ Age squared } & $0.000027^{* *}$ & $0.000039^{* * *}$ & $0.000015^{* * *}$ & $0.000013^{* * *}$ \\
\hline & $(0.000012)$ & $(0.000011)$ & $(0.000000)$ & $(0.000000)$ \\
\hline \multirow[t]{2}{*}{ Semi-detached house (dummy) } & $-0.110702^{* * *}$ & $-0.082331^{* * *}$ & $-0.080268^{* * *}$ & 0.038174 \\
\hline & $(0.023410)$ & $(0.021941)$ & $(0.024052)$ & $(0.032361)$ \\
\hline \multirow[t]{2}{*}{ Row house end unit (dummy) } & $-0.334135^{* * *}$ & $-0.207371^{* * *}$ & $-0.094348^{* * *}$ & $-0.126463^{* * *}$ \\
\hline & $(0.057144)$ & $(0.030815)$ & $(0.024206)$ & $(0.046543)$ \\
\hline \multirow[t]{2}{*}{ Row house (dummy) } & $-0.359443^{* * *}$ & $-0.179267^{* * *}$ & $-0.176109 * * *$ & $-0.101679^{* *}$ \\
\hline & $(0.050525)$ & $(0.027107)$ & $(0.027401)$ & $(0.047684)$ \\
\hline \multirow[t]{2}{*}{ Individual construction (dummy) } & - & - & $-0.112581^{* *}$ & - \\
\hline & - & - & $(0.044543)$ & - \\
\hline Further building characteristics controlled & yes & yes & no & yes \\
\hline \multirow[t]{2}{*}{ Land value (Euro per m²) } & $0.002894^{* * *}$ & $0.003257^{* * *}$ & $0.002501^{* * *}$ & $0.009712^{* * *}$ \\
\hline & $(0.000458)$ & $(0.000288)$ & $(0.000174)$ & $(0.001343)$ \\
\hline \multirow[t]{2}{*}{ Log of vacancy rate } & $-0.103369^{* *}$ & $-0.077700^{* * *}$ & $-0.115598^{* * *}$ & $-0.083429^{*}$ \\
\hline & $(0.043830)$ & $(0.021815)$ & $(0.032039)$ & $(0.047308)$ \\
\hline \multirow[t]{2}{*}{ Inhabitants (thousands) } & 0.000707 & $-0.001147^{* *}$ & 0.000106 & 0.002719 \\
\hline & $(0.000752)$ & $(0.000498)$ & $(0.000529)$ & $(0.001681)$ \\
\hline \multirow[t]{2}{*}{ Population density (k inhabitants per $\mathrm{km}^{2}$ ) } & $0.333660^{* * *}$ & 0.033489 & $-0.101654^{* *}$ & 0.069839 \\
\hline & $(0.064657)$ & $(0.073548)$ & $(0.041207)$ & $(0.183784)$ \\
\hline \multirow[t]{2}{*}{ Population density squared } & $-0.214914^{* * *}$ & $-0.179961^{* * *}$ & -0.073296 & $-1.084909^{* * *}$ \\
\hline & $(0.061461)$ & $(0.042597)$ & $(0.044624)$ & $(0.333186)$ \\
\hline \multirow[t]{2}{*}{ Per capita income (k Euro) } & $0.027525^{* * *}$ & $0.034322^{* * *}$ & 0.002713 & 0.014736 \\
\hline & $(0.007981)$ & $(0.004683)$ & $(0.003895)$ & $(0.012388)$ \\
\hline \multirow[t]{2}{*}{ Local property tax leverage factor (percent) } & 0.033164 & -0.011396 & $0.101506^{* * *}$ & 0.028602 \\
\hline & $(0.051551)$ & $(0.020197)$ & $(0.038171)$ & $(0.048046)$ \\
\hline \multirow[t]{2}{*}{ Local public spending per inhabitant (k Euro) } & - & $0.054108^{* * *}$ & $0.082079^{* *}$ & - \\
\hline & - & $(0.019332)$ & $(0.035253)$ & - \\
\hline \multirow[t]{2}{*}{ Constant } & $11.295008^{* * *}$ & $11.737404^{* * *}$ & $12.182819^{* * *}$ & $11.225707^{* * *}$ \\
\hline & $(0.101222)$ & $(0.064812)$ & $(0.021486)$ & $(0.139925)$ \\
\hline $\mathrm{AIC}$ & $2,478.37$ & 285.96 & 872.76 & $1,979.29$ \\
\hline $\mathrm{BIC}$ & $2,576.51$ & 529.35 & 966.86 & $2,084.61$ \\
\hline Adjusted $\mathrm{R}^{2}$ & 0.674164 & 0.740878 & 0.646972 & 0.650050 \\
\hline Number of observations & 2,375 & 1,866 & 1,874 & 1,888 \\
\hline
\end{tabular}

Table 2: Baseline regression results. Continuous variables are mean-centered. Standard errors reported in parentheses are cluster-robust clustering at the municipality level. The reference category for property type is "detached house“. Lot size for BB is winsorized for one extreme value. Price for $\mathrm{RP}$ is winsorized for one extreme value. Living space for $\mathrm{RP}$ is winsorized for three extreme values. Lot size for SA is winsorized for one extreme value. Building age is winsorized for SA for 28 extreme values. 
higher qualities of micro location, are associated with higher sales prices. Including municipality-level indicators of location quality (as described in Section 3.2) instead of property-level land values yields significant coefficients with plausible signs (see Table A3 in the appendix). The coefficients turn insignificant once property-specific land values are added to the model. ${ }^{24}$

The evidence for municipality-level controls is somewhat mixed across the four states. We do not find consistent significance for municipality size, population density, the squared value of population density and the local property tax level. In line with housing being a normal good, SFH tend to sell at higher prices were per capita income is higher: the corresponding coefficient is significant for Brandenburg and Lower Saxony. Local public spending also tends to be positively associated with individual sales prices while simultaneously controlling for property tax and income levels. This result is likely to reflect that municipalities spending heavily on local public goods generate positive externalities, although caution is warranted due to the incomplete control of local variation in service fee and non-property tax levels.

Since many additional property characteristics contain missing values across different observations, we run alternative specifications that only include the most basic property-level characteristics along with the municipal vacancy rate as regressors. ${ }^{25}$ This allows approximately doubling the sample size for Lower Saxony and enlarging it by several hundreds of observations for Brandenburg and SaxonyAnhalt. ${ }^{26}$ Goodness of fit measures indicate that the group of basic property attributes alone already explains a great deal of variation in house prices. More importantly, the coefficients estimated on the vacancy rate remain unchanged concerning their economic magnitude and statistical significance.

\subsection{Robustness Checks}

We run several robustness checks concerning the sensitivity of our main result to changes in model specification, the exclusion of multivariate outliers, and to accounting for potential endogeneity of the vacancy rate. We additionally perform randomized out-of-sample predictions to investigate the external validity of the regression results.

\footnotetext{
years in LS, 217 in RP and 188 years in SA.

${ }^{24}$ The adjusted goodness of fit rises by about five percentage points when using property-level land values alone.

${ }^{25}$ Results are reported in Table A4 in the appendix.

${ }^{26}$ from $\mathrm{N}=1,866$ to $\mathrm{N}=3,464$ for $\mathrm{LS}$, from $\mathrm{N}=2,375$ to $\mathrm{N}=2,850$ for $\mathrm{BB}$ and from $\mathrm{N}=1,888$ to $\mathrm{N}=2,478$ for $\mathrm{SA}$.
} 


\section{Model Specification}

Every model specification must necessarily be partly driven by subjective considerations and may therefore be put into question. For example, higher powers or interactions of variables may be omitted from the specification despite their true relevance, leading to omitted variables bias. Belloni et al. (2014) recently suggests the Least Absolute Shrinkage and Selection Operator („LASSO“) as a purely data-driven approach of model specification. ${ }^{27}$ The procedure chooses covariates by means of a maximization algorithm that aims at identifying the specification with the best out-of-sample prediction properties from the data. We use LASSO to check the validity of our choice of variables and the robustness of the link between sales prices and local vacancies to the inclusion of powers and (multiple) interaction terms between variables. Compared to the baseline model, the relationship between house prices and the rate of vacancy remains largely unchanged, becoming somewhat less pronounced in absolute terms in RhinelandPalatinate. Only for Saxony-Anhalt, the effect we find is not anymore statistically different from zero. ${ }^{28}$

\section{Influential Observations}

In a second robustness check, we take into consideration potential bias from influential observations and multivariate outliers. We already used winsorizing to make observations with obvious errors or inaccuracies in one or more variables suitable for regression analysis. ${ }^{29}$ We additionally resort to Cook's D (Cook and Weisberg, 1982) in order to scan the data for multivariate influential outliers and exclude suspicious observations from the regressions. Table A6 in the appendix reports specifications identical to the baseline regression model in Table 2, without observations associated with Cook's D values larger than the recommended threshold of $4 / N$. Our main result remains qualitatively unchanged in each state.

\section{Instrumental Variable Approach}

The local vacancy rate potentially suffers from an endogeneity problem in our baseline specification. First, despite controlling for a battery of property- and municipality-level characteristics, there may be latent unobserved factors correlated with local vacancies that also influence individual house prices. Second, a reverse causality issue may arise from incentives to leave houses vacant when

\footnotetext{
${ }^{27}$ The procedure has been implemented with the user-written command „lassoShooting“ in Stata.

${ }^{28}$ Table A5 in the appendix reports the outcome of the LASSO procedure, with the vacancy rate as ex ante fixed variable with controls selected by Lasso included but not shown.

${ }^{29}$ Through winsorizing, extremely high or low variable values are replaced by the next-smallest or next-largest value from another observation in the data set.
} 
nearby house prices are low. It is important to note that reverse causality is not seen as a serious problem in most of the wage curve literature: as Nijkamp and Poot (2005) point out in a review, less than ten percent of empirical studies on the wage curve include instrumental variables. The reason is that it is unlikely that random shocks to a micro outcome (a labor contract or the price negotiated in an individual home transaction) unfold any systematic feedback effects on a macro variable (the local aggregate unemployment or housing vacancy rate).

In order to infer whether the observed downward-sloping curve among selling prices and vacancies is indeed conducive to a causal interpretation, we use information on long-lagged historical local vacancy. Historical data contains exogenous variation in vacancies that must necessarily be unrelated to contemporaneous shocks to selling prices. This approach again has its analogy in the wage curve literature, where lagged unemployment rates are often used as instruments for current ones (Blanchflower and Oswald, 2005). The exclusion restriction is that lagged vacancy rates have an impact on current SFH transaction prices no other than through the channel of being correlated to current levels of vacancy. For western Germany, the last historical Census providing detailed data on vacant dwellings was conducted in 1987, while the according year is 1995 for eastern Germany. The vacancy computation method has been comparable in all three years. ${ }^{30}$ It seems plausible that vacancy rates are persistent over time, suggesting pronounced correlations between vacancy rates in 1987/1995 and 2011. Indeed, the bivariate correlation between the two variables for municipalities in which we observe home transactions in 2011 ranges from 0.189 for Rhineland-Palatinate to 0.360 in Lower Saxony. This indicates potential instrument relevance, which we test in the first stage.

Table 3 shows the output from a two-stage least squares regression of the baseline model with municipal vacancy rates in 1987/1995 used as instruments for 2011 vacancy rates. In the first stage regressions, historical vacancy rates always carry the expected positive signs and are statistically significant at the ten percent level or better for three of four states. The p-value of the instrumented vacancy rate in the second stage indicates significance only for Brandenburg. Most importantly, robust score tests never reject the null of contemporaneous vacancy rates being exogenous to individual price shocks for all four states. This result is in line with the view that random deviations in prices negotiated in individual home transactions are unlikely to exhibit feedback effects on local vacancy rates theirselves. ${ }^{31}$ Against this background, the IV exercise suggests

\footnotetext{
${ }^{30}$ In each Census wave, dwelling owners were asked whether their dwelling was currently owner-occupied, rented out, a holiday or recreational home, or vacant. Short-term, interim vacant homes due to renovation, modernization or tenant moves were not counted as vacant in each Census wave. For each Census year, we subtract all holiday and recreational homes from the total number of local dwellings in the calculation of local vacancy rates.

${ }^{31}$ For Saxony-Anhalt, this result must be treated with care due to the instrument being weak.
} 
that our main result survives potential endogeneity of current vacancy and lends itself to a causal interpretation.

\section{External Validity}

We finally assess the external validity of the regression results. To this end, we employ out-of-sample predictions of sales prices by randomly excluding five percent of transactions from all four samples and re-estimating the model for each state. We predict sales prices for the excluded cases based on the coefficients obtained by estimating the baseline regression (Table 2). Figures A5-A8 in the appendix illustrate the resulting scatterplots of actual against predicted selling prices. We see that our model performs generally well in predicting out-of-sample sales prices.

\section{Time Persistence of Local Housing Vacancies}

If higher vacancies indeed induce lower sales prices, high-vacancy areas become relatively more attractive to buyers. In competitive and frictionless housing markets, this mechanism would ensure elevated vacancies to return to normal levels. In view of the empirical evidence in favor of a negatively sloped house-price vacancy curve, the extent to which vacancies in local housing markets are timepersistent is therefore a crucial question from a wider economic perspective: even if vacancies are associated with negative price signals, adjustment through disinvestment or an influx of new buyers may take decades due to the extreme durability of housing (Glaeser and Gyourko, 2005). Policy intervention becomes a viable option once housing markets fail to clear even in the long-run despite economically „correct“ price signals of elevated vacancies.

Recent research on local housing dynamics indeed shows housing markets to be much less liquid than other asset markets and failing to easily re-equilibrate in response to shocks (Zabel, 2014). ${ }^{32}$ For the labor market (another market requiring search and matching), Blanchard et al. (1992) show regional unemployment rates in U.S. states to be time-persistent, with labor mobility (not real wage declines) eventually leading them to return to initial levels after random shocks. Similar adjustment can be severely impeded in the housing market due to the immobility and indivisibility of properties, high transaction costs (Haurin and Gill, 2002) and downward-inelastic supply (Glaeser and Gyourko, 2005; Maennig and Dust, 2008). Much as labor markets, housing moreover exhibits downward stickiness in prices (Genesove and Mayer, 2001)

To address these questions, we empirically test whether there are systematic

\footnotetext{
${ }^{32}$ Earlier, DiPasquale and Wheaton (1994) and Riddel (2004) have provided evidence that housing markets exhibit extended periods of disequilibrium.
} 


\begin{tabular}{|c|c|c|c|c|}
\hline State & $\mathrm{BB}$ & LS & $\mathrm{RP}$ & $\mathrm{SA}$ \\
\hline \multicolumn{5}{|l|}{ Variable } \\
\hline \multirow[t]{2}{*}{ Lot size $\left(\mathrm{m}^{2}\right)$} & $0.000017^{*}$ & $0.000127^{* * *}$ & $0.000206^{* * *}$ & $0.000210^{* * *}$ \\
\hline & $(0.000010)$ & $(0.000025)$ & $(0.000049)$ & $(0.000027)$ \\
\hline \multirow[t]{2}{*}{ Living space $\left(\mathrm{m}^{2}\right)$} & $0.006044^{* * *}$ & $0.002791^{* * *}$ & $0.003512^{* * *}$ & $0.004081^{* * *}$ \\
\hline & $(0.000273)$ & $(0.000192)$ & $(0.000287)$ & $(0.000596)$ \\
\hline \multirow[t]{2}{*}{ Age (years) } & $-0.007397^{* * *}$ & $-0.009628^{* * *}$ & $-0.006600^{* * *}$ & $-0.005010^{* * *}$ \\
\hline & $(0.000427)$ & $(0.000671)$ & $(0.000463)$ & $(0.000337)$ \\
\hline \multirow[t]{2}{*}{ Age squared } & $0.000026^{* *}$ & $0.000038^{* * *}$ & $0.000015^{* * *}$ & $0.000013^{* * *}$ \\
\hline & $(0.000012)$ & $(0.000011)$ & $(0.000002)$ & $(0.000001)$ \\
\hline \multirow[t]{2}{*}{ Semi-detached house (dummy) } & $-0.105637^{* * *}$ & $-0.085959^{* * *}$ & $-0.077578^{* * *}$ & 0.056434 \\
\hline & $(0.024273)$ & $(0.022316)$ & $(0.024151)$ & $(0.037854)$ \\
\hline \multirow[t]{2}{*}{ Row house end unit (dummy) } & $-0.323631^{* * *}$ & $-0.212546^{* * *}$ & $-0.089775^{* * *}$ & $-0.104055^{* *}$ \\
\hline & $(0.057913)$ & $(0.031276)$ & $(0.024458)$ & $(0.050301)$ \\
\hline \multirow[t]{2}{*}{ Row house (dummy) } & $-0.351832^{* * *}$ & $-0.182474 * * *$ & $-0.172292^{* * *}$ & $-0.096258^{* *}$ \\
\hline & $(0.050732)$ & $(0.026238)$ & $(0.026525)$ & $(0.047684)$ \\
\hline \multirow[t]{2}{*}{ Individual construction (dummy) } & - & - & $-0.112152^{* *}$ & - \\
\hline & - & - & $(0.046301)$ & - \\
\hline Further building characteristics controlled & yes & yes & no & yes \\
\hline \multirow[t]{2}{*}{ Land value (Euro per $\mathrm{m}^{2}$ ) } & $0.002958^{* * *}$ & $0.003446^{* * *}$ & $0.002665^{* * *}$ & $0.008693^{* * *}$ \\
\hline & $(0.000389)$ & $(0.000311)$ & $(0.000274)$ & $(0.001611)$ \\
\hline \multirow[t]{2}{*}{ Log of vacancy rate } & $-0.242725^{*}$ & 0.016136 & 0.019362 & -0.531868 \\
\hline & $(0.134153)$ & $(-0.064321)$ & $(0.179620)$ & $(0.430973)$ \\
\hline \multirow[t]{2}{*}{ Inhabitants (thousands) } & 0.000434 & $0.000995^{* *}$ & 0.000306 & 0.003467 \\
\hline & $(0.000809)$ & $(0.000458)$ & $(0.000631)$ & $(0.002170)$ \\
\hline \multirow[t]{2}{*}{ Population density ( $\mathrm{k}$ inhabitants per $\mathrm{km}^{2}$ ) } & $0.300131^{* * *}$ & 0.054894 & -0.060478 & 0.323927 \\
\hline & $(0.080175)$ & $(0.070672)$ & $(0.068819)$ & $(0.361649)$ \\
\hline \multirow[t]{2}{*}{ Population density squared } & $-0.173772^{* *}$ & $-0.163311^{* * *}$ & -0.095089 & $-1.522743^{* * *}$ \\
\hline & $(0.070296)$ & $(0.038276)$ & $(0.059794)$ & $(0.578058)$ \\
\hline \multirow[t]{2}{*}{ Per capita income (k Euro) } & 0.011659 & $0.039912^{* * *}$ & 0.004242 & -0.023609 \\
\hline & $(0.016280)$ & $(0.005772)$ & $(0.004988)$ & $(0.039781)$ \\
\hline \multirow[t]{2}{*}{ Local property tax leverage factor (percent) } & 0.052511 & -0.021448 & $0.079488^{*}$ & 0.066632 \\
\hline & $(0.054665)$ & $(0.020464)$ & $(0.045774)$ & $(0.080494)$ \\
\hline \multirow[t]{2}{*}{ Local public spending per inhabitant (k Euro) } & - & $0.039021^{*}$ & 0.047258 & - \\
\hline & - & $(0.020221)$ & $(0.063448)$ & - \\
\hline \multirow[t]{2}{*}{ Constant } & $11.483411^{* * *}$ & $11.745434^{* * *}$ & $12.189965^{* * *}$ & $11.654802^{* * *}$ \\
\hline & $(0.194680)$ & $(0.068392)$ & $(0.025579)$ & $(0.450878)$ \\
\hline $\mathrm{AIC}$ & - & - & - & - \\
\hline $\mathrm{BIC}$ & - & - & - & - \\
\hline Adjusted $\mathrm{R}^{2}$ & 0.668773 & 0.736019 & 0.643112 & 0.622781 \\
\hline Number of observations & 2,375 & 1,853 & 1,861 & 1,888 \\
\hline Dependent variable: $\log$ of transaction price & \multicolumn{4}{|c|}{${ }^{*} \mathrm{p}<0.1 ; * * \mathrm{p}<0.05 ; * * * \mathrm{p}<0.01$} \\
\hline
\end{tabular}

Robust regression-based test statistic of vacancy rate in 2011 being exogenous:

BB: $\mathrm{F}(1,285)=0.74384(\mathrm{p}=0.3892)$

LS: $\mathrm{F}(1,435)=2.63153(\mathrm{p}=0.1055)$

$\mathrm{RP}: \mathrm{F}(1,434)=0.64524(\mathrm{p}=0.4223)$

SA: $\mathrm{F}(1,175)=1.98349(\mathrm{p}=0.1608)$

Table 3: Instrumental Variable regression results of the second stage, where the vacancy rate in 2011 is instrumented by the vacancy rate in 1987 for western states and 1995 for eastern states. All continuous variables are mean centered. Standard errors reported in parentheses are cluster-robust clustering at the municipality level. The reference category for property type is "detached house". Lot size for BB is winsorized for one extreme value. Lot size for SA is winsorized for extreme high value. Building age is winsorized for SA for 28 extreme values. 
patterns of persistence in housing vacancies at the municipal level over time. ${ }^{33}$ To this end, we again use the information on historical small-scale vacancy rates in the four different states compiled in previous censuses. Table 4 shows state-bystate results for a straightforward quantitative test of vacancy persistence over time: a regression of the 2011 vacancy rate on historical rates and a set of indicator variables capturing structural differences between municipalities in terms of centrality, settlement type, and long-term growth. For the two eastern states, we additionally include a dummy variable that reflects whether a municipality participated in federal urban redevelopment programs (Stadtumbau Ost in German) during the time period of 1995 and 2011.

\begin{tabular}{|c|c|c|c|c|}
\hline State & BB & LS & $\mathbf{R P}$ & SA \\
\hline Dep. Var. & $V^{2011}$ & $V^{2011}$ & $V^{2011}$ & $V^{2011}$ \\
\hline$V^{1987 / 95}$ & $0.1637^{* * *}$ & $0.4909^{* * *}$ & $0.1014^{*}$ & $0.3193^{* * *}$ \\
\hline Constant & $-0.0300 * * *$ & $0.0658^{* * *}$ & $-0.0347^{* * *}$ & $-0.0105^{*}$ \\
\hline \multicolumn{5}{|c|}{ Controlling for: } \\
\hline Settlement type & yes & yes & yes & yes \\
\hline Growth type & yes & yes & yes & yes \\
\hline Centrality & yes & yes & yes & yes \\
\hline Urban redev. & yes & no & no & yes \\
\hline$R^{2}$ & 0.2292 & 0.3178 & 0.0293 & 0.1952 \\
\hline$N$ & 419 & 1006 & 2304 & 219 \\
\hline
\end{tabular}

Table 4: Testing for time persistence in municipal vacancy rates in the states of Brandenburg (BB), Lower Saxony (LS), Rhineland-Palatinate (RP) and Saxony-Anhalt (SA). Regressions control for three different settlement types (rural to urban), five different growth types (fastly growing to strongly shrinking) and four different centrality types (very central to very peripheral), in Brandenburg and Saxony Anhalt additionally for participation in federal urban redevelopment programs. ${ }^{*}, * *, * * *$ denote statistical significance at the $1 \%, 5 \%$ and $10 \%$-level based on Huber-White robust standard errors.

All state panels reveal strictly positive partial correlations among contemporaneous and historical vacancy rates, displayed as differences from the sample mean in the respective years. The regression coefficients are statistically significant throughout, ranging between 0.10 in Rhineland-Palatinate and 0.49 in Lower Saxony. The evidence thus strongly supports the notion of strong temporal persistence in housing vacancy rates: housing markets in below-average vacancy municipalities in 1987/1995 remain comparatively strong, whereas municipalities with above-average historical vacancies do not close the gap within time periods

\footnotetext{
${ }^{33}$ To our knowledge, similar work has so far been carried out only for local office markets, typically guided by some a priori assumptions about the dynamic behaviour of vacancy derived from structural models (Grenadier, 1995). Despite its obvious relevance for policy, the question of persistence in small-scale housing vacancy rates over time has hardly been tackled by empirical work.
} 
of several decades. ${ }^{34}$ The evidence thus corroborates the assumption that smallscale housing markets do not work efficiently when it comes to dealing with excess supply: price discounts associated with higher rates of local vacancy are apparently not strong enough to raise demand to sufficient levels and eventually bring back vacancy to state-normal levels. ${ }^{35}$

\section{Conclusions}

This study has investigated the role of nearby residential vacancies in the price determination of single-family homes. Based on a review of theoretical and empirical papers on housing market search and matching and housing externalities, the key hypothesis of a house price-vacancy curve - a systematic inverse association between individual selling prices and vacancies in the neighborhood - was developed that is invariant to geography and therefore represents a symmetric case of the well-established concept of a wage curve in labor economics. Based on data on more than 10,000 single-family home sales in four different German states, spatially granular vacancy rates and further local characteristics, firsttime empirical evidence has been provided in favor of the existence of such a fundamental relationship. The quantitative link between local vacancy rates and individual home prices turns out to be strikingly similar across the four states: when the vacancy rate in a municipality doubles, quality-controlled single-family home prices decrease by about $5-8 \%$. The full economic costs of elevated vacancy rates are likely to be underestimated by these price effects alone, given that high vacancies are associated with increased marketing time and may even completely forestall economically desirable sales.

Our key finding poses a striking but previously undocumented analogy to the wage curve in labor economics, a concept that captures the quantitative effect of variation in local unemployment on individual wages. The elasticity of wages with respect to aggregate local unemployment has long been documented for many countries, is of very similar magnitude and is referred to as an empirical law in economics (Blanchflower and Oswald, 2005). A similar elasticity of home prices to local vacancies lends further support to the idea that housing markets

\footnotetext{
${ }^{34}$ As a numerical example, two thirds of all municipalities in Saxony Anhalt had either above or below-average vacancy rates in both 1995 and 2011. For a similar result on local office markets, see Grenadier (1995).

${ }^{35}$ Zabel (2014) recently provides similar evidence for larger-scale (U.S. metropolitan) housing markets. Against the background of shrinking and aging populations in many industrialized economies (especially in rural areas), the question arises to what extent such findings imply the possibility of a downward spiral of low selling prices making properties in high-vacancy areas even less attractive for potential investors and hence generating local populations to decline further, leading to even more vacant houses. Our paper only gives a first hint in this regard by highlighting the substantial time-persistence of local vacancy rates despite the empirical fact of a price discount of higher vacancies. Policymakers should watch high-vacancy areas carefully and potentially implement ways to correct permanent housing market disequilibria.
} 
are best analyzed in terms of search, bargaining and matching instead of perfect competition. This matches a key second stylized fact we have reported in this paper: the fact that local housing vacancy distributions display strong persistence over fairly long time horizons despite the presence of sales price discounts through higher vacancies. This persistence can be interpreted as a sign of market failure that leaves room for policy intervention. Molloy (2016) points out recently that because locations with unusually high vacancy tend to be fairly heterogeneous, the efficacy of policies aimed at reducing local vacancy rates will depend on the type of neighborhood being considered.

As with any empirical study, there are limitations that must be put on the results of this paper. Although we manage to control for a large number of possibly confounding factors, as well as for potential endogeneity of local vacancy rates, the question of whether the results allow establishing any definite statement about causality remains necessarily controversial. We nevertheless remain confident that a robust empirical link between individual house prices and local vacancies provides a useful foundation for further research: first and foremost, it would be highly interesting to extend the analysis to other countries with different housing market designs. Further research may also examine whether the observed relationship holds for other types of housing, such as non-regulated rental housing or owner-occupied apartments. In terms of discriminating among potential channels that generate a house price-vacancy curve, it looks promising to investigate more deeply whether systematic differences exist in the empirical sensitivity of house prices to local vacancy between homes of different age or type. Comparable research in the labor market literature has suggested systematic differences in wage sensitivity to unemployment according to workers' age or gender (Nijkamp and Poot, 2005; Blanchflower and Oswald, 2005). Finally, random-assignment experimental research could shed further light on the question of whether information on local vacancy rates causally affects individual bargaining behavior and eventually translates into different sales prices. 


\section{References}

Anenberg, E. and Kung, E. (2014). Estimates of the size and source of price declines due to nearby foreclosures. American Economic Review, 104(8):252751.

Belloni, A., Chernozhukov, V., and Hansen, C. (2014). Inference on treatment effects after selection among high-dimensional controls. The Review of Economic Studies, 81(2):608-650.

Blanchard, O. J., Katz, L. F., Hall, R. E., and Eichengreen, B. (1992). Regional evolutions. Brookings Papers on Economic Activity, pages 1-75.

Blanchflower, D. and Oswald, A. (1994). The wage curve. MIT press.

Blanchflower, D. and Oswald, A. (2005). The wage curve reloaded. NBER Working Paper, (11338).

Campbell, J. Y., Giglio, S., and Pathak, P. (2011). Forced sales and house prices. American Economic Review, 101(5):2108-31.

Card, D. (1995). The wage curve: A review. Journal of Economic Literature, $33(2): 785$.

Cohen, J., Coughlin, C., and Clapp, J. (2015). Local polynomial regressions versus ols for generating location value estimates: Which is more efficient in out-of-sample forecasts? Federal Reserve Bank of St. Louis Working Paper Series, (2015-014).

Cook, R. D. and Weisberg, S. (1982). Criticism and influence analysis in regression. Sociological Methodology, 13(3):313-361.

Diamond, P. (1982). Wage determination and efficiency in search equilibrium. The Review of Economic Studies, 49(2):217-227.

DiPasquale, D. and Wheaton, W. (1996). Urban economics and real estate markets. Prentice Hall, Englewood Cliffs, NJ.

DiPasquale, D. and Wheaton, W. C. (1994). Housing market dynamics and the future of housing prices. Journal of Urban Economics, 35(1):1-27.

Forgey, F. A., Rutherford, R. C., and Springer, T. M. (1996). Search and liquidity in single-family housing. Real Estate Economics, 24(3):273-292.

Gabriel, S. A. and Nothaft, F. E. (2001). Rental housing markets, the incidence and duration of vacancy, and the natural vacancy rate. Journal of Urban Economics, 49(1):121-149. 
Genesove, D. and Han, L. (2012). Search and matching in the housing market. Journal of Urban Economics, 72(1):31-45.

Genesove, D. and Mayer, C. (2001). Loss aversion and seller behavior: evidence from the housing market. Quarterly Journal of Economics, 116(4):1233-1260.

Gerardi, K., Rosenblatt, E., Willen, P. S., and Yao, V. (2015). Foreclosure externalities: New evidence. Journal of Urban Economics, 87:42 - 56.

Glaeser, E. L. and Gyourko, J. (2005). Urban decline and durable housing. Journal of Political Economy, 113(2):345-375.

Grenadier, S. R. (1995). Local and national determinants of office vacancies. Journal of Urban Economics, 37(1):57-71.

Hartley, D. (2014). The effect of foreclosures on nearby housing prices: Supply or dis-amenity? Regional Science and Urban Economics, 49:108-117.

Haurin, D. R. and Gill, H. L. (2002). The impact of transaction costs and the expected length of stay on homeownership. Journal of Urban Economics, 51(3):563-584.

Ihlanfeldt, K. and Mayock, T. (2016). The variance in foreclosure spillovers across neighborhood types. Public Finance Review, 44(1):80-108.

Krainer, J. (2001). A theory of liquidity in residential real estate markets. Journal of Urban Economics, 49(1):32-53.

Lin, Z., Rosenblatt, E., and Yao, V. W. (2009). Spillover effects of foreclosures on neighborhood property values. The Journal of Real Estate Finance and Economics, 38(4):387-407.

Maennig, W. and Dust, L. (2008). Shrinking and growing metropolitan areas asymmetric real estate price reactions? The case of German single-family houses. Regional Science and Urban Economics, 38(1):63-69.

Mian, A., Sufi, A., and Trebbi, F. (2015). Foreclosures, house prices, and the real economy. The Journal of Finance, 70(6):2587-2634.

Molloy, R. (2016). Long-term vacancy in the United States. Regional Science and Urban Economics, 59(7):118-129.

Mortensen, D. (1982). The matching process as a noncooperative bargaining game. In The economics of information and uncertainty, pages 233-258. University of Chicago Press. 
Moulton, B. R. (1990). An illustration of a pitfall in estimating the effects of aggregate variables on micro units. The Review of Economics and Statistics, pages $334-338$.

Ngai, L. R. and Tenreyro, S. (2014). Hot and cold seasons in the housing market. American Economic Review, 104(12):3991-4026.

Nijkamp, P. and Poot, J. (2005). The last word on the wage curve? Journal of Economic Surveys, 19(3):421-450.

Piazzesi, M., Schneider, M., and Stroebel, J. (2015). Segmented housing search. NBER Working Paper, (20823).

Pissarides, C. (1990). Equilibrium unemployment theory. MIT press.

Riddel, M. (2004). Housing-market disequilibrium: an examination of housingmarket price and stock dynamics 1967-1998. Journal of Housing Economics, 13(2):120-135.

Rosen, K. T. and Smith, L. B. (1983). The price-adjustment process for rental housing and the natural vacancy rate. The American Economic Review, 73(4):779-786.

Rosen, S. (1974). Hedonic prices and implicit markets: product differentiation in pure competition. The Journal of Political Economy, 82(1):34-55.

Rossi-Hansberg, E., Sarte, P.-D., and Owens III, R. (2010). Housing externalities. Journal of Political Economy, 118(3).

Sheppard, S. (1999). Hedonic analysis of housing markets. Handbook of Regional and Urban Economics, 3:1595-1635.

Stein, J. (1995). Prices and trading volume in the housing market: A model with down-payment effects. The Quarterly Journal of Economics, 110(2):379-406.

Wheaton, W. (1990). Vacancy, search, and prices in a housing market matching model. Journal of Political Economy, 98(6):1270-1292.

Whitaker, S. and Fitzpatrick, T. J. (2013). Deconstructing distressed-property spillovers: The effects of vacant, tax-delinquent, and foreclosed properties in housing submarkets. Journal of Housing Economics, 22(2):79-91.

Williams, J. T. (1995). Pricing real assets with costly search. Review of Financial Studies, 8(1):55-90.

Wooldridge, J. M. (2010). Econometric analysis of cross section and panel data. MIT press. 
Zabel, J. (2014). A dynamic model of the housing market: The role of vacancies. The Journal of Real Estate Finance and Economics, pages 1-24. 


\section{Appendix}

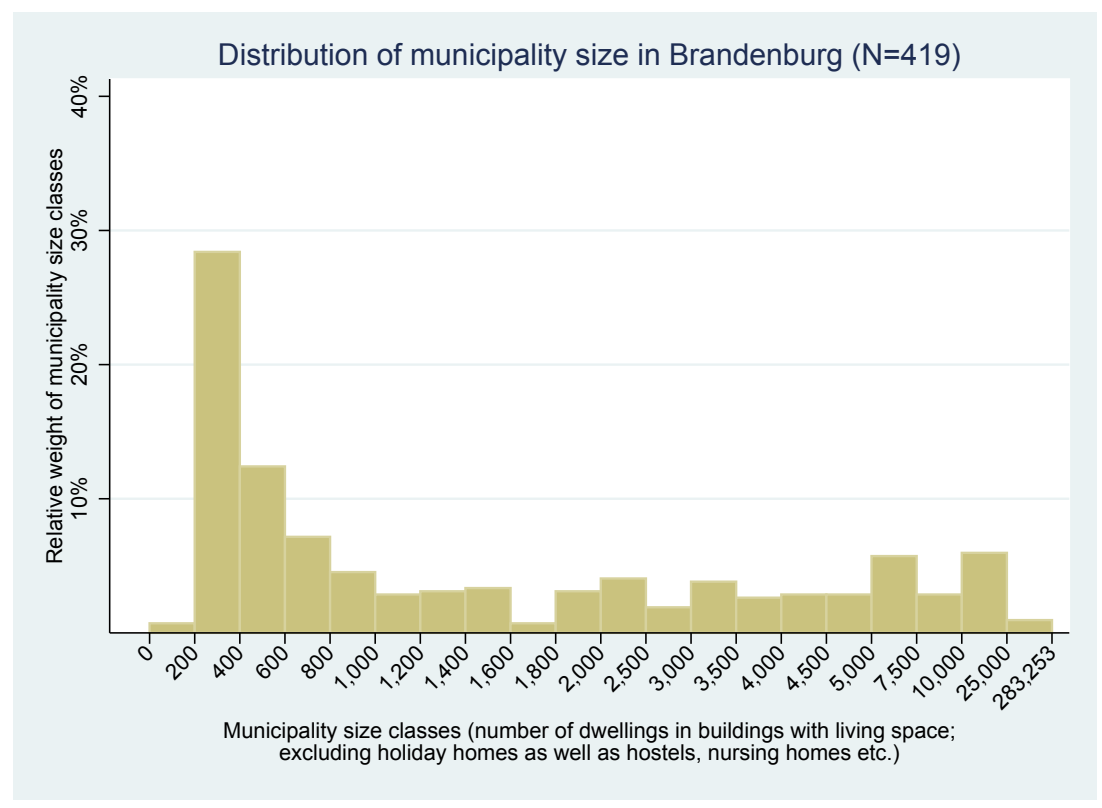

Figure A1: Histogram Brandenburg

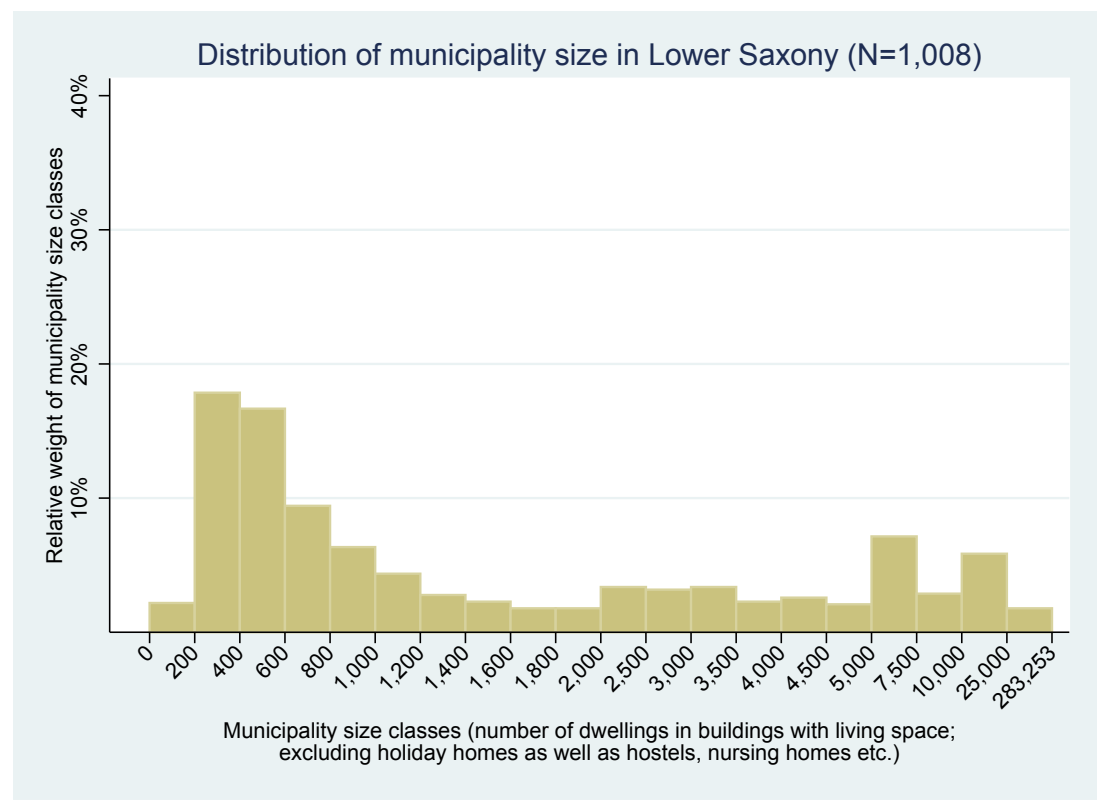

Figure A2: Histogram Lower Saxony 


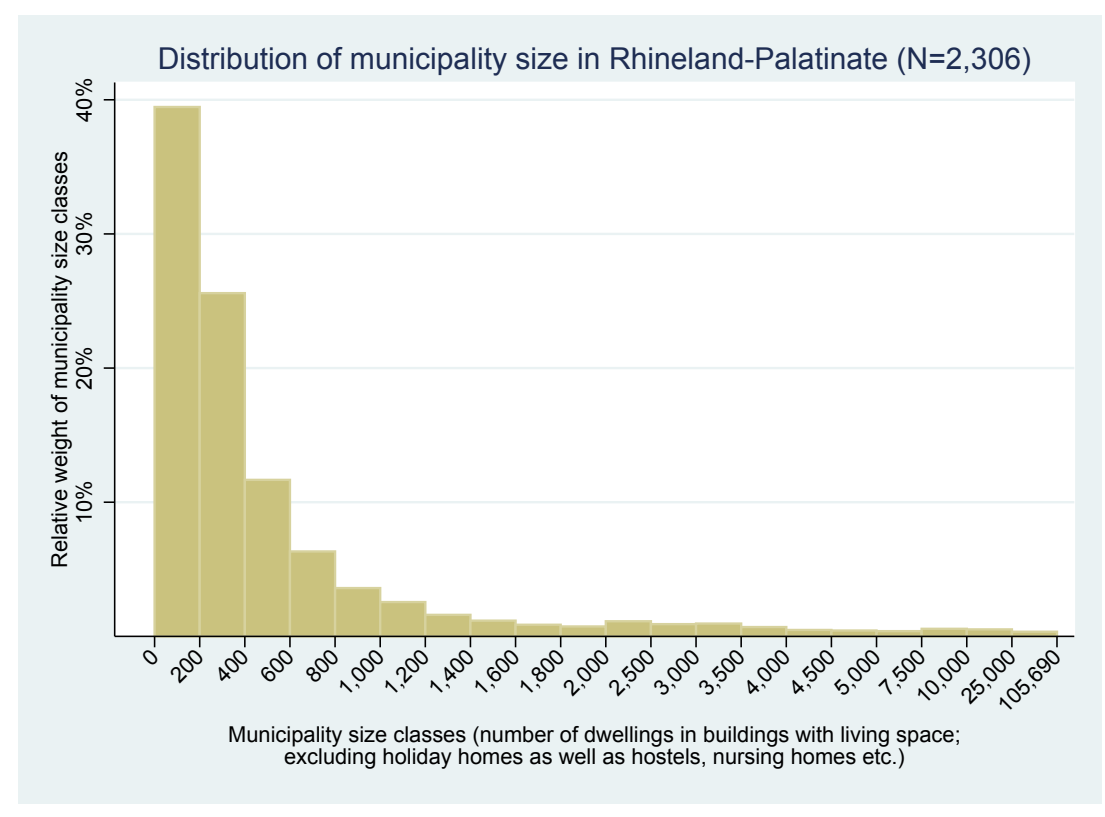

Figure A3: Histogram Rhineland-Palatinate

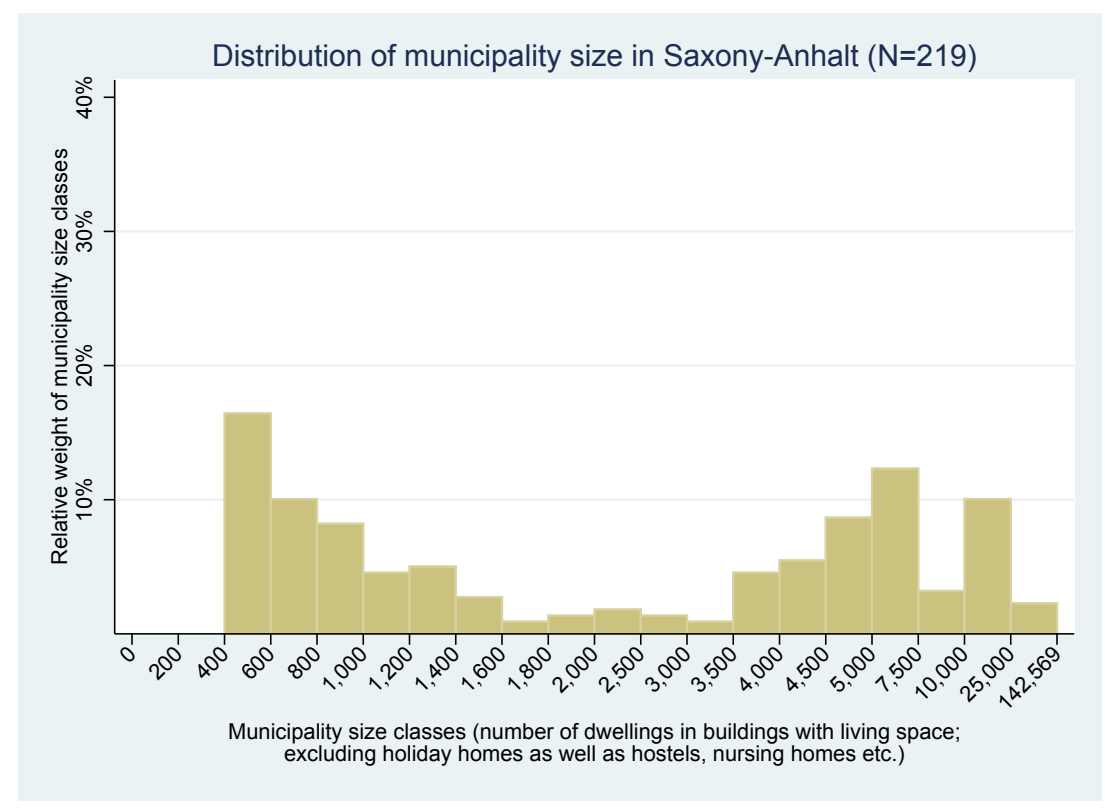

Figure A4: Histogram Saxony-Anhalt 


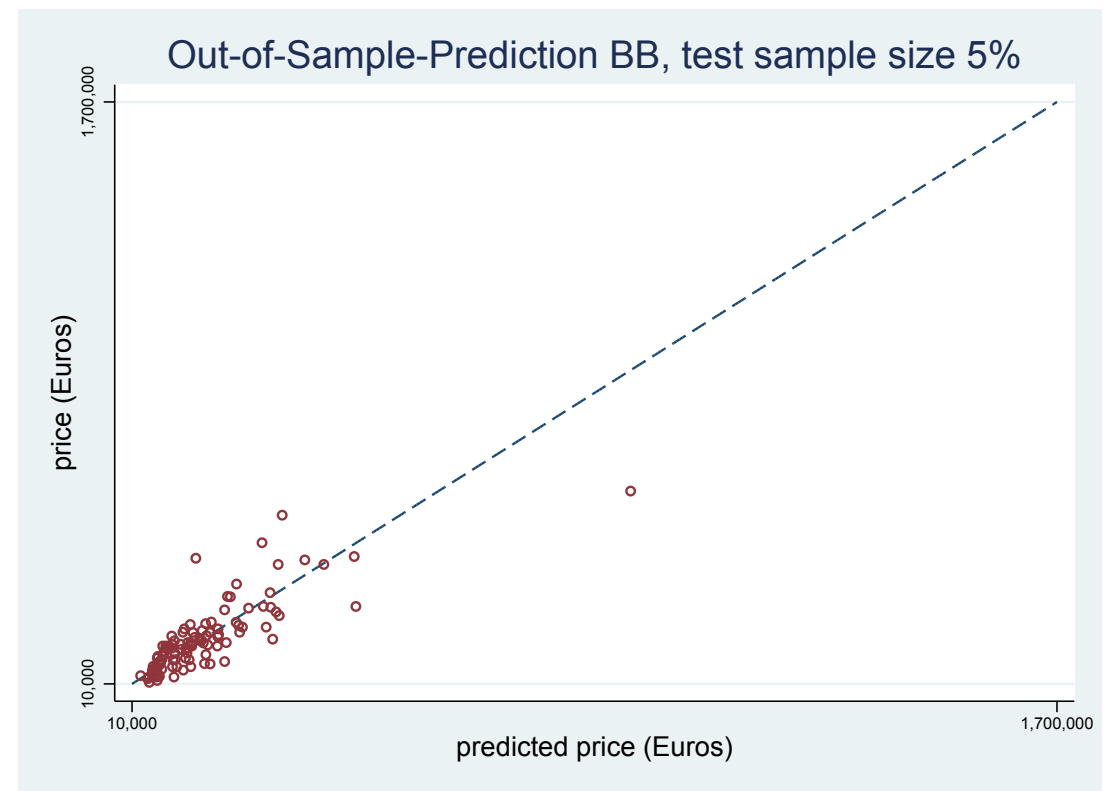

Figure A5: Out-of-sample-prediction for a 5\% subsample of observations in Brandenburg, based on the specification used for the baseline results in Table 2.

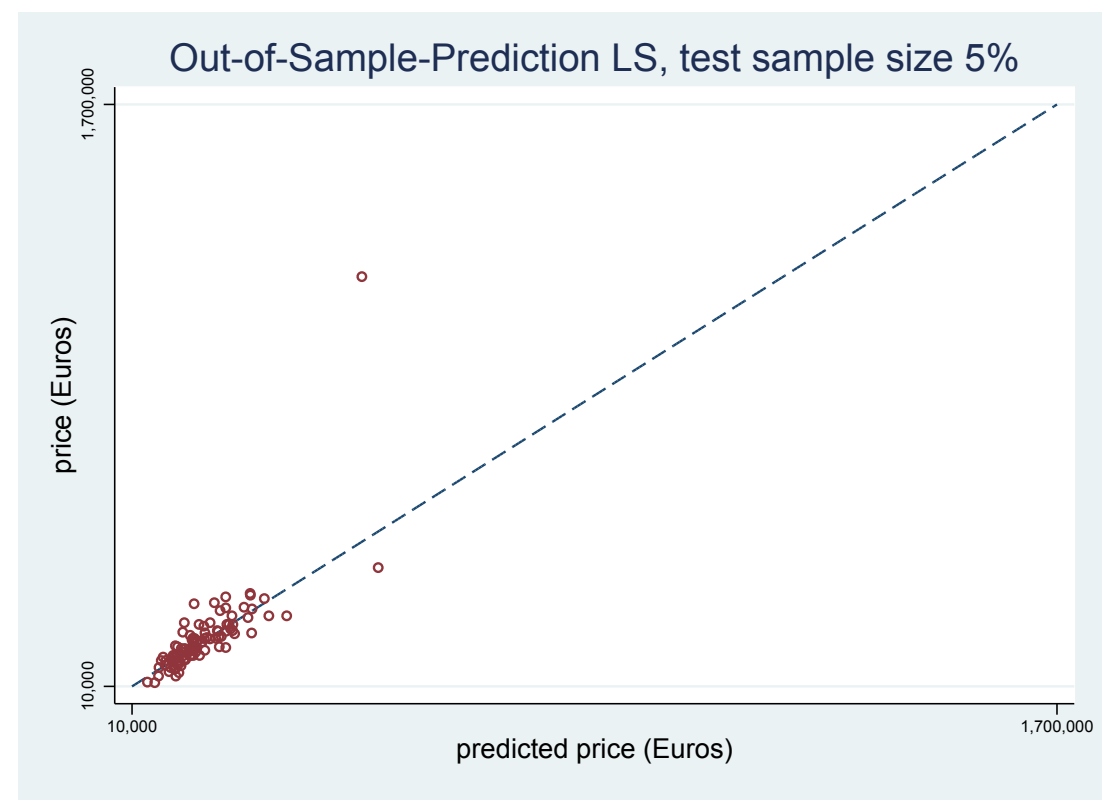

Figure A6: Out-of-sample-prediction for a 5\% subsample of observations in Lower Saxony, based on the specification used for the baseline results in Table 2 . 


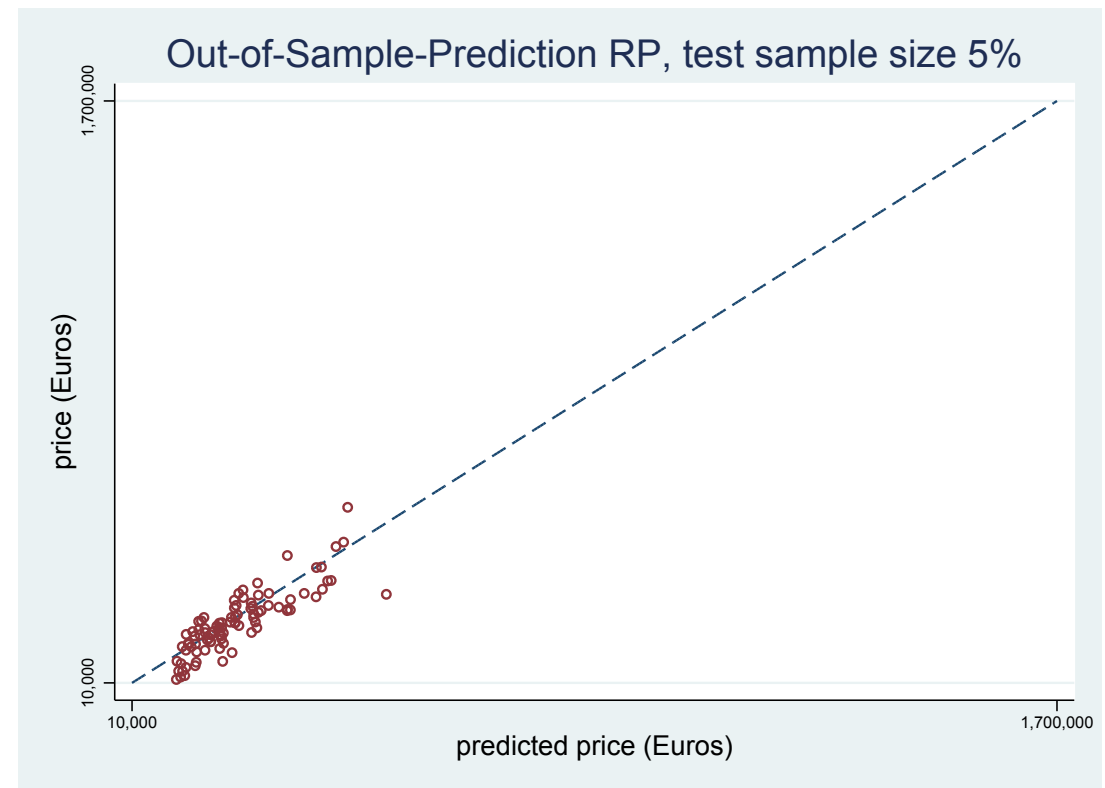

Figure A7: Out-of-sample-prediction for a $5 \%$ subsample of observations in RhinelandPalatinate, based on the specification used for the baseline results in Table 2.

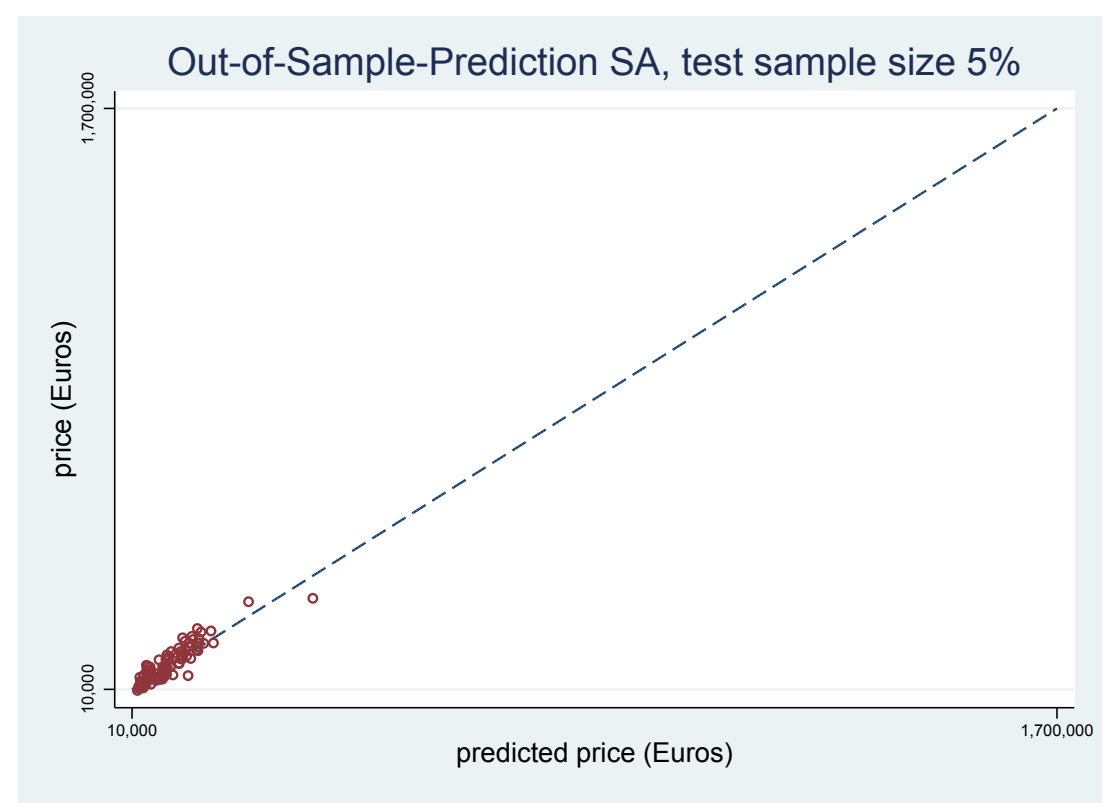

Figure A8: Out-of-sample-prediction for a 5\% subsample of observations in Saxony-Anhalt, based on the specification used for the baseline results in Table 2. 


\section{Variable \\ Property characteristics}

Transaction price

Lot size

Living space

Age

Land value

Type of building indicators

\section{Municipality characteristics}

Vacancy rate

Inhabitants

Population density

Per capita income

Ratio SFH of total dwellings

Local property tax leverage factor

Local public spending per inhabitant

Urban redevelopment

Location type

Settlement type

Growth type

Definition

Source

Transaction price of SFH in Euro

Lot size of $\mathrm{SFH}$ in $\mathrm{m}^{2}$

Living space of $\mathrm{SFH}$ in $\mathrm{m}^{2}$

Building age of $\mathrm{SFH}$ in years

Publicly registered land value of a lot in Euro per $\mathrm{m}^{2}$

Indicator for detached, semi-detached and row houses

Ratio of vacant dwellings to total dwellings less holiday homes

Number of inhabitants in thousands

Number of inhabitants in thousands per $\mathrm{km}^{2}$

Taxable income per inhabitant in thousands of Euros in 2007

Percentage of SFHs relative to all dwellings

Local property tax leverage factor (Grundsteuer B) in percent

Local public spending per inhabitant in thousands of Euros

Dummy for participation of a municipality in the urban redevelopment program "Stadtumbau Ost"

Classification of municipalities into "very central", "central",

"peripheral" or "very peripheral"

Classification of municipalities into "mostly urban", "partly urban" or "rural"

Classification of municipalities into "strongly growing",

"growing", "stable", "shrinking" or "severely shrinking"
Superior Committees of Valuation

Experts of Lower Saxony,

Rhineland-Palatinate and Saxony-Anhalt

Censuses 1987, 1995 and 2011, Federal Statistical Office Census 2011, Federal Statistical Office

Census 2011, Federal Statistical Office

Income tax statistics, Federal Statistical Office

Census 2011, Federal Statistical Office

Tax leverage factor statistics (Hebesätze der Realsteuern), Federal Statistical Office Municipality budget statistics (vierteljährliche Kassenstatistik der Gemeinden), Federal Statistical Office Ministry for Infrastructure and Regional Planning Brandenburg, Ministry for Regional Development and Transport Saxony-Anhalt

Federal Institute for Research on Building, Urban Affairs and Spatial Development (Bundesinstitut für Bau-, Stadtund Raumforschung, short BBSR)

Federal Institute for Research on Building, Urban Affairs and Spatial Development (Bundesinstitut für Bau-, Stadtund Raumforschung, short BBSR)

Federal Institute for Research on Building, Urban Affairs and Spatial Development (Bundesinstitut für Bau-, Stadtund Raumforschung, short BBSR) 


\begin{tabular}{|c|c|c|c|}
\hline State & $\mathrm{BB}$ & LS & $\mathrm{SA}$ \\
\hline \multicolumn{4}{|l|}{ Variable } \\
\hline Lot size $\left(\mathrm{m}^{2}\right)$ & $0.000017^{*}$ & $0.000123^{* * *}$ & $0.000209^{* * *}$ \\
\hline Living space $\left(\mathrm{m}^{2}\right)$ & $0.005972^{* * *}$ & $0.002793^{* * *}$ & $0.004041^{* * * *}$ \\
\hline Age (years) & $-0.007538 * * *$ & $-0.009336 * * *$ & $-0.004885^{* * *}$ \\
\hline Age squared & $0.000027^{* *}$ & $0.000039^{* * *}$ & $0.000013^{* * *}$ \\
\hline Semi-detached house (dummy) & $-0.110702^{* * *}$ & $-0.082331 * * *$ & 0.038174 \\
\hline Row house end unit (dummy) & $-0.334135 * * *$ & $-0.207371^{* * *}$ & $-0.126463 * * *$ \\
\hline Row house (dummy) & $-0.359443^{* * *}$ & $-0.179267^{* * *}$ & $-0.101679 * *$ \\
\hline Individual construction (dummy) & - & - & - \\
\hline Land value (Euro per $\mathrm{m}^{2}$ ) & $0.002894^{* * *}$ & $0.003257^{* * *}$ & $0.009712^{* * *}$ \\
\hline Roof type "octagonal" & - & 0.111037 & - \\
\hline Roof type "rainbow roof' & - & - & - \\
\hline Roof type "flat roof" & - & 0.024393 & - \\
\hline Roof type "mansard roof" & - & 0.092952 & - \\
\hline Roof type "monopitch roof" & - & -0.052227 & - \\
\hline Roof type "hip roof' & - & $0.035553^{*}$ & - \\
\hline Roof type "tented roof, conical roof, dome roof" & - & -0.056672 & - \\
\hline Roof type "other roof type" & - & -0.040329 & - \\
\hline Attic in place & - & 0.011735 & - \\
\hline Prefabricated house & - & -0.026893 & - \\
\hline Garage or parking space in place & - & -0.018231 & - \\
\hline Quality of windows "elaborate" & - & 0.031855 & - \\
\hline Quality of windows "simple" & - & $-0.101604 * * *$ & - \\
\hline Regional type "tourist center" & - & -0.057703 & - \\
\hline Regional type "city fringe area" & - & -0.030531 & - \\
\hline Regional type "cities and Oberzentren" & - & $0.099950^{* *}$ & - \\
\hline Regional type "Grundzentren" & - & $0.054521^{* * *}$ & - \\
\hline Regional type "Mittelzentren" & - & $0.051172^{* *}$ & - \\
\hline Refurbishment status 'few modernisation works" & - & -0.017192 & - \\
\hline Refurbishment status 'average" & - & 0.020376 & - \\
\hline Refurbishment status 'largely modernised" & - & 0.014675 & - \\
\hline Transaction took place between natural persons & - & 0.071969 & - \\
\hline General equipment standard 'basic' & - & $-0.200398^{* * *}$ & $-0.588587^{* * *}$ \\
\hline General equipment standard 'basic to average' & - & $-0.129237^{* * *}$ & $-0.408338 * * *$ \\
\hline General equipment standard 'average to upscale" & - & $0.098124^{* * *}$ & $0.196788^{* * *}$ \\
\hline General equipment standard 'upscale" & - & $0.166640^{* * *}$ & $0.331086^{* * *}$ \\
\hline General equipment standard 'upscale to highly upscale" & - & $0.597727^{* * *}$ & $0.124852^{*}$ \\
\hline General equipment standard 'highly upscale' & - & $0.284003^{* * *}$ & - \\
\hline Celler (at least 50 percent of building area) & $0.105908^{* * *}$ & - & - \\
\hline Number of floors & 0.038005 & - & - \\
\hline Log of vacancy rate & $-0.103369^{* *}$ & $-0.077700^{* * *}$ & $-0.083429^{*}$ \\
\hline Inhabitants (thousands) & 0.000707 & $-0.001147^{* *}$ & 0.002719 \\
\hline Population density ( $\mathrm{k}$ inhabitants per $\mathrm{km}^{2}$ ) & $0.333660^{* * *}$ & 0.033489 & 0.069839 \\
\hline Population density squared & $-0.214914^{* * *}$ & $-0.179961 * * *$ & $-1.084909^{* * *}$ \\
\hline Per capita income (k Euro) & $0.027525 * * *$ & $0.034322^{* * *}$ & 0.014736 \\
\hline Local property tax leverage factor (percent) & 0.033164 & -0.011396 & 0.028602 \\
\hline Local public spending per inhabitant ( $\mathrm{k}$ Euro) & - & $0.054108^{* * *}$ & - \\
\hline Constant & $11.295008^{* * *}$ & $11.737404^{* * * *}$ & $11.225707^{* * *}$ \\
\hline AIC & $2,478.37$ & 285.96 & $1,979.29$ \\
\hline BIC & $2,576.51$ & 529.35 & $2,084.61$ \\
\hline Adjusted $\mathrm{R}^{2}$ & 0.674164 & 0.740878 & 0.650050 \\
\hline Number of observations & 2.375 & 1.866 & 1.888 \\
\hline
\end{tabular}

Table A2: Baseline regression results, full results. All continuous variables are mean centered. Standard errors reported in parentheses are cluster-robust clustering at the municipality level. The reference category for property type is „detached house“. The reference category for roof type is "saddle roof, half-hip roof“. The reference category for quality of windows is „average“. The reference category for location type is „villages“. The reference category for refurbishment status is „not modernised“. The reference category for general equipment standard is "average“. Lot size for BB is winsorized for one extreme value. Lot size for SA is winsorized for one extreme value. Building age is winsorized for SA for 28 extreme values. 


\begin{tabular}{|c|c|c|c|c|}
\hline State & $\mathrm{BB}$ & LS & $\mathrm{RP}$ & SA \\
\hline \multicolumn{5}{|l|}{ Variable } \\
\hline \multirow[t]{2}{*}{ Lot size $\left(\mathrm{m}^{2}\right)$} & 0.000018 & $0.000101^{* * *}$ & $0.000180^{* * *}$ & $0.000157^{* * *}$ \\
\hline & $(0.000011)$ & $(0.000024)$ & $(0.000047)$ & $(0.000028)$ \\
\hline \multirow[t]{2}{*}{ Living space $\left(\mathrm{m}^{2}\right)$} & $0.006243^{* * *}$ & $0.003052^{* * *}$ & $0.004022^{* * *}$ & $0.004434^{* * *}$ \\
\hline & $(0.000299)$ & $(0.000205)$ & $(0.000294)$ & $(0.000630)$ \\
\hline \multirow[t]{2}{*}{ Age (years) } & $-0.007814^{* * *}$ & $-0.009182^{* * *}$ & $-0.007100^{* * *}$ & $-0.005681^{* * *}$ \\
\hline & $(0.000491)$ & $(0.000615)$ & $(0.000473)$ & $(0.000376)$ \\
\hline \multirow[t]{2}{*}{ Age squared } & $0.000032^{* *}$ & $0.000036^{* * *}$ & $0.000016^{* * *}$ & $0.000015^{* * *}$ \\
\hline & $(0.000013)$ & $(0.000011)$ & $(0.000000)$ & $(0.000000)$ \\
\hline \multirow[t]{2}{*}{ Semi-detached house (dummy) } & $-0.082110^{* * *}$ & $-0.070626^{* * *}$ & $-0.070250^{* *}$ & 0.055686 \\
\hline & $(0.022702)$ & $(0.022158)$ & $(0.028406)$ & $(0.034710)$ \\
\hline \multirow[t]{2}{*}{ Row house end unit (dummy) } & $-0.280650^{* * *}$ & $-0.213048^{* * *}$ & -0.037870 & $-0.103499^{* *}$ \\
\hline & $(0.067685)$ & $(0.025480)$ & $(0.031965)$ & $(0.049893)$ \\
\hline \multirow[t]{2}{*}{ Row house (dummy) } & $-0.304809^{* * *}$ & $-0.162079^{* * *}$ & $-0.133665^{* * *}$ & -0.049937 \\
\hline & $(0.046846)$ & $(0.027777)$ & $(0.033425)$ & $(0.051967)$ \\
\hline \multirow[t]{2}{*}{ Individual construction (dummy) } & - & - & $-0.184563^{* * *}$ & - \\
\hline & - & - & $(0.046684)$ & - \\
\hline Further building characteristics controlled & yes & yes & no & yes \\
\hline \multirow[t]{2}{*}{ Log of vacancy rate } & -0.059390 & $-0.113290^{* * *}$ & $-0.218059^{* * *}$ & $-0.154593^{* * *}$ \\
\hline & $(0.038309)$ & $(0.020639)$ & $(0.042116)$ & $(0.048394)$ \\
\hline \multirow[t]{2}{*}{ Central (location type dummy) } & -0.037694 & $-0.098274^{*}$ & $-0.1298552^{* *}$ & $-0.123935^{*}$ \\
\hline & $(0.041434)$ & $(0.054580)$ & $(0.051223)$ & $(0.067392)$ \\
\hline \multirow[t]{2}{*}{ Peripheral (location type dummy) } & $-0.154150^{* *}$ & $-0.182095^{* * *}$ & $-0.191244^{* * *}$ & $-0.142547^{* * *}$ \\
\hline & $(0.065928)$ & $(0.061716)$ & $(0.062139)$ & $(0.050409)$ \\
\hline \multirow[t]{2}{*}{ Very peripheral (location type dummy) } & $-0.266934^{* * *}$ & $-0.153796^{* *}$ & $-0.187242^{* *}$ & - \\
\hline & $(0.072696)$ & $(0.075278)$ & $(0.088882)$ & - \\
\hline \multirow[t]{2}{*}{ Partly urban (settlement type dummy) } & 0.051612 & 0.004328 & $-0.074465^{*}$ & 0.096095 \\
\hline & $(0.053996)$ & $(0.028620)$ & $(0.042501)$ & $(0.063711)$ \\
\hline \multirow[t]{2}{*}{ Rural (settlement type dummy) } & -0.098692 & -0.030775 & -0.063371 & 0.088654 \\
\hline & $(0.064069)$ & $(0.034477)$ & $(0.051357)$ & $(0.092939)$ \\
\hline \multirow[t]{2}{*}{ Inhabitants (thousands) } & $0.001839^{* * *}$ & 0.000604 & $0.002717^{* * *}$ & $0.006035^{* * *}$ \\
\hline & $(0.000558)$ & $(0.000576)$ & $(0.000751)$ & $(0.001691)$ \\
\hline \multirow[t]{2}{*}{ Population density ( $\mathrm{k}$ inhabitants per $\mathrm{km}^{2}$ ) } & $0.232306^{* * *}$ & $0.162877^{*}$ & 0.011544 & $0.564963^{* *}$ \\
\hline & $(0.084639)$ & $(0.085318)$ & $(0.055047)$ & $(0.308756)$ \\
\hline \multirow[t]{2}{*}{ Population density squared } & $-0.081644^{*}$ & $-0.158529^{* * *}$ & $-0.181956^{* * *}$ & $-1.976321^{* * *}$ \\
\hline & $(0.044354)$ & $(0.055641)$ & $(0.061856)$ & $(0.487067)$ \\
\hline \multirow[t]{2}{*}{ Per capita income (k Euro) } & $0.034743^{* * *}$ & $0.045888^{* * *}$ & $0.010463^{* *}$ & $0.039304^{* *}$ \\
\hline & $(0.005819)$ & $(0.005457)$ & $(0.004561)$ & $(0.015136)$ \\
\hline \multirow[t]{2}{*}{ Local property tax leverage factor (percent) } & 0.028200 & 0.018898 & 0.029937 & 0.048887 \\
\hline & $(0.043210)$ & $(0.023152)$ & $(0.051499)$ & $(0.052966)$ \\
\hline \multirow[t]{2}{*}{ Local public spending per inhabitant (k Euro) } & - & $0.082146^{* * *}$ & -0.060937 & - \\
\hline & - & $(0.020999)$ & $(0.042255)$ & - \\
\hline \multirow[t]{2}{*}{ Constant } & $11.287549^{* * *}$ & $11.790790^{* * *}$ & $12.306110^{* * *}$ & $11.105710^{* * *}$ \\
\hline & $(0.087422)$ & $(0.081616)$ & $(0.040380)$ & $(0.160222)$ \\
\hline $\mathrm{AIC}$ & $2,463.60$ & 473.18 & $1,152.30$ & $2,123.93$ \\
\hline $\mathrm{BIC}$ & $2,584.83$ & 738.69 & $1,268.55$ & 2245.88 \\
\hline Adjusted $\mathrm{R}^{2}$ & 0.676724 & 0.714129 & 0.591045 & 0.622779 \\
\hline Number of observations & 2,375 & 1,866 & 1,874 & 1,888 \\
\hline
\end{tabular}

Table A3: Baseline regression results, aggregate municipality-level controls for location instead of publicly registered land value. All continuous variables are mean centered. Standard errors reported in parentheses are cluster-robust clustering at the municipality level. The reference category for property type is "detached house“. Lot size for BB is winsorized for one extreme value. Price for RP is winsorized for one extreme value. Living space for RP is winsorized for three extreme values. Lot size for SA is winsorized for one extreme value. Building age is winsorized for SA for 28 extreme values. 


\begin{tabular}{|c|c|c|c|c|}
\hline State & $\mathrm{BB}$ & LS & $\mathrm{RP}$ & $\mathrm{SA}$ \\
\hline \multicolumn{5}{|l|}{ Variable } \\
\hline \multirow[t]{2}{*}{ Lot size $\left(\mathrm{m}^{2}\right)$} & $0.000018^{*}$ & $0.000087^{* * *}$ & $0.000199^{* * *}$ & $0.000177^{* * *}$ \\
\hline & $(0.000010)$ & $(0.000018)$ & $(0.000044)$ & $(0.000033)$ \\
\hline \multirow[t]{2}{*}{ Living space $\left(\mathrm{m}^{2}\right)$} & $0.005970^{* * *}$ & $0.003901^{* * *}$ & $0.003578^{* * *}$ & $0.006066^{* * *}$ \\
\hline & $(0.000305)$ & $(0.000188)$ & $(0.000276)$ & $(0.000598)$ \\
\hline \multirow[t]{2}{*}{ Age (years) } & $-0.007568^{* * *}$ & $-0.010186^{* * *}$ & $-0.006029^{* * *}$ & $-0.007591^{* * *}$ \\
\hline & $(0.000359)$ & $(0.000408)$ & $(0.000431)$ & $(0.000358)$ \\
\hline \multirow[t]{2}{*}{ Age squared } & $0.000017^{* *}$ & $0.000046^{* * *}$ & $0.000012^{* * *}$ & $0.000019^{* * *}$ \\
\hline & $(0.000007)$ & $(0.000007)$ & $(0.000002)$ & $(0.000001)$ \\
\hline \multirow[t]{2}{*}{ Semi-detached house (dummy) } & $-0.119188^{* * *}$ & $-0.091351^{* * *}$ & $-0.049590^{*}$ & $0.074313^{* *}$ \\
\hline & $(0.026498)$ & $(0.016247)$ & $(0.000184)$ & $(0.031407)$ \\
\hline \multirow[t]{2}{*}{ Row house end unit (dummy) } & $-0.316215^{* * *}$ & $-0.166330^{* * *}$ & $-0.062846^{* *}$ & $-0.189849^{* * *}$ \\
\hline & $(0.047583)$ & $(0.028812)$ & $(0.028903)$ & $(0.052077)$ \\
\hline \multirow[t]{2}{*}{ Row house (dummy) } & $-0.340271^{* * *}$ & $-0.190578^{* * *}$ & $-0.141312^{* * *}$ & $-0.094640^{* *}$ \\
\hline & $(0.048239)$ & $(0.028893)$ & $(0.028937)$ & $(0.045314)$ \\
\hline \multirow[t]{2}{*}{ Individual construction (dummy) } & - & - & $-0.133897^{* * *}$ & - \\
\hline & & & $(0.051552)$ & \\
\hline \multirow[t]{2}{*}{ Land value (Euro per m²) } & $0.005451^{* * *}$ & $0.004733^{* * *}$ & $0.002365^{* * *}$ & $0.010147^{* * *}$ \\
\hline & $(0.000493)$ & $(0.000219)$ & $(0.000184)$ & $(0.000970)$ \\
\hline \multirow[t]{2}{*}{ Log of vacancy rate } & $-0.194105^{* * *}$ & $-0.072491^{* * *}$ & $-0.060993^{*}$ & -0.014812 \\
\hline & $(0.041390)$ & $(0.026776)$ & $(0.033302)$ & $(0.055475)$ \\
\hline \multirow[t]{2}{*}{ Constant } & $11.647380^{* * *}$ & $11.785369^{* * *}$ & $12.147135^{* * *}$ & $11.046734^{* * *}$ \\
\hline & $(0.020399)$ & $(0.012172)$ & $(0.014247)$ & $(0.027553)$ \\
\hline $\mathrm{AIC}$ & $3,373.50$ & $1,553.36$ & 937.85 & $3,704.79$ \\
\hline $\mathrm{BIC}$ & $3,433.05$ & $1,614.87$ & 998.75 & $3,762.94$ \\
\hline Adjusted $\mathrm{R}^{2}$ & 0.645444 & 0.673814 & 0.633330 & 0.516041 \\
\hline Number of observations & 2,850 & 3,464 & 1,874 & 2,478 \\
\hline
\end{tabular}

Table A4: Baseline regression results, object characteristics only. All continuous variables are mean centered. Standard errors reported in parentheses are cluster-robust clustering at the municipality level. The reference category for property type is „detached house“. Lot size for $\mathrm{BB}$ is winsorized for one high value. Price for RP is winsorized for one high value. Living space for RP is winsorized for three high values. Lot size for SA is winsorized for one high value. Building age is winsorized for SA for 28 high values. 


\begin{tabular}{lcccc} 
State & BB & LS & RP & SA \\
\hline Variable & \multicolumn{1}{c}{ yes } & yes & yes & yes \\
\hline Lasso procedure controls & $-0.061230^{*}$ & $-0.083460^{* * *}$ & $-0.057107^{*}$ & -0.032705 \\
Log of vacancy rate & $(0.031074)$ & $(0.019768)$ & $(0.030798)$ & $(0.052248)$ \\
& $11.686115^{* * *}$ & $11.799901^{* * *}$ & $12.123543^{* * *}$ & $11.198015^{* * *}$ \\
Constant & $(0.020417)$ & $(0.010697)$ & $(0.013162)$ & $(0.018420)$ \\
\hline AIC & $3,073.10$ & 326.11 & 1095.39 & 3729.86 \\
BIC & $3,186.18$ & 508.83 & 1150.75 & 3809.88 \\
Adjusted ${ }^{2}$ & 0.679903 & 0.733259 & 0.600984 & 0.430172 \\
Number of observations & 2,840 & 1,876 & 1,873 & 2,244 \\
\hline Dependent variable: $\log$ of transaction price & & $* \mathrm{p}<0.1 ; * * \mathrm{p}<0.05 ; * * * \mathrm{p}<0.01$
\end{tabular}

Table A5: Regression results based on explanatory variables chosen by Lasso algorithm. For selecting the variables, all possible interaction terms between variables are allowed. All continuous variables are mean centered. Standard errors reported in parentheses are cluster-robust clustering at the municipality level. The reference category for property type is „detached house". 


\begin{tabular}{|c|c|c|c|c|}
\hline State & $\mathrm{BB}$ & LS & $\mathrm{RP}$ & SA \\
\hline \multicolumn{5}{|l|}{ Variable } \\
\hline \multirow[t]{2}{*}{ Lot size $\left(\mathrm{m}^{2}\right)$} & 0.000018 & $0.000167^{* * *}$ & $0.000236^{* * *}$ & $0.000207^{* * *}$ \\
\hline & $(0.000017)$ & $(0.000019)$ & $(0.000025)$ & $(0.000020)$ \\
\hline \multirow[t]{2}{*}{ Living space $\left(\mathrm{m}^{2}\right)$} & $0.005879^{* * *}$ & $0.002659^{* * *}$ & $0.002955^{* * *}$ & $0.004411^{* * *}$ \\
\hline & $(0.000272)$ & $(0.000166)$ & $(0.000164)$ & $(0.000300)$ \\
\hline \multirow[t]{2}{*}{ Age (years) } & $-0.007568^{* * *}$ & $-0.009665^{* * *}$ & $-0.006510^{* * *}$ & $-0.004810^{* * *}$ \\
\hline & $(0.000397)$ & $(0.000464)$ & $(0.000366)$ & $(0.000264)$ \\
\hline \multirow[t]{2}{*}{ Age squared } & $0.000041^{* * *}$ & $0.000036^{* * *}$ & $0.000018^{* * *}$ & $0.000012^{* * *}$ \\
\hline & $(0.000009)$ & $(0.000007)$ & $(0.000003)$ & $(0.000001)$ \\
\hline \multirow[t]{2}{*}{ Semi-detached house (dummy) } & $-0.105105^{* * *}$ & $-0.077349 * * *$ & $-0.092013^{* * *}$ & 0.018409 \\
\hline & $(0.019425)$ & $(0.016811)$ & $(0.019885)$ & $(0.024685)$ \\
\hline \multirow[t]{2}{*}{ Row house end unit (dummy) } & $-0.296034^{* * *}$ & $-0.198457^{* * *}$ & $-0.106753^{* * *}$ & -0.055167 \\
\hline & $(0.032499)$ & $(0.025388)$ & $(0.023514)$ & $(0.034072)$ \\
\hline \multirow[t]{2}{*}{ Row house (dummy) } & $-0.378713^{* * *}$ & $-0.151786^{* * *}$ & $-0.177426^{* * *}$ & $-0.093573^{* *}$ \\
\hline & $(0.041929)$ & $(0.020668)$ & $(0.023575)$ & $(0.037198)$ \\
\hline \multirow[t]{2}{*}{ Individual construction (dummy) } & - & - & $-0.088103^{* * *}$ & - \\
\hline & - & - & $(0.029009)$ & - \\
\hline Further building characteristics controlled & yes & yes & no & yes \\
\hline \multirow[t]{2}{*}{ Land value (Euro per $\mathrm{m}^{2}$ ) } & $0.002724^{* * *}$ & $0.003275^{* * *}$ & $0.002647^{* * *}$ & $0.009325^{* * *}$ \\
\hline & $(0.000372)$ & $(0.000272)$ & $(0.000129)$ & $(0.000974)$ \\
\hline \multirow[t]{2}{*}{ Log of vacancy rate } & $-0.105881^{* * *}$ & $-0.054793^{* * *}$ & $-0.099217^{* * *}$ & $-0.082642^{* *}$ \\
\hline & $(0.029660)$ & $(0.014995)$ & $(0.027191)$ & $(0.037838)$ \\
\hline \multirow[t]{2}{*}{ Inhabitants (thousands) } & 0.000510 & $0.001032^{* * *}$ & -0.000671 & $0.002225^{* *}$ \\
\hline & $(0.000518)$ & $(0.000365)$ & $(0.000441)$ & $(0.001076)$ \\
\hline \multirow[t]{2}{*}{ Population density ( $\mathrm{k}$ inhabitants per $\mathrm{km}^{2}$ ) } & $0.308173^{* * *}$ & 0.044952 & $-0.101143^{* * *}$ & 0.067316 \\
\hline & $(0.057123)$ & $(0.059893)$ & $(0.032730)$ & $(0.116216)$ \\
\hline \multirow[t]{2}{*}{ Population density squared } & $-0.221853^{* * *}$ & $-0.165935^{* * *}$ & -0.020590 & $-0.881603^{* * *}$ \\
\hline & $(0.050949)$ & $(0.033035)$ & $(0.032992)$ & $(0.231027)$ \\
\hline \multirow[t]{2}{*}{ Per capita income (k Euro) } & $0.027352^{* * *}$ & $0.034436^{* * *}$ & -0.002785 & 0.011311 \\
\hline & $(0.005581)$ & $(0.003824)$ & $(0.003049)$ & $(0.008545)$ \\
\hline \multirow[t]{2}{*}{ Local property tax leverage factor (percent) } & 0.038794 & -0.011446 & $0.087376^{* * *}$ & 0.011893 \\
\hline & $(0.037228)$ & $(0.018373)$ & $(0.031418)$ & $(0.032511)$ \\
\hline \multirow[t]{2}{*}{ Local public spending per inhabitant (k Euro) } & - & $0.063967^{* * *}$ & $0.127395^{* * *}$ & - \\
\hline & - & $(0.016680)$ & $(0.029241)$ & - \\
\hline \multirow[t]{2}{*}{ Constant } & $11.298927^{* * *}$ & $11.753895^{* * *}$ & $12.172463^{* * *}$ & $11.371777^{* * * *}$ \\
\hline & $(0.071508)$ & $(0.044746)$ & $(0.019744)$ & $(0.038164)$ \\
\hline $\mathrm{AIC}$ & $1,362.28$ & -392.63 & -83.70 & $1,101.94$ \\
\hline $\mathrm{BIC}$ & $1,459.61$ & -173.52 & 9.55 & $1,206.31$ \\
\hline Adjusted $\mathrm{R}^{2}$ & 0.740445 & 0.787284 & 0.723216 & 0.714462 \\
\hline Number of observations & 2,266 & 1,768 & 1,781 & 1,796 \\
\hline
\end{tabular}

Table A6: Baseline regression results without influential observations (Cook's D > 4/N, corresponding to 0.00168 for Brandenburg, 0.00214 for Lower Saxony, 0.00213 for RhinelandPalatinate and 0.00212 for Saxony-Anhalt). All continuous variables are mean centered. Standard errors reported in parentheses are cluster-robust clustering at the municipality level. The reference category for property type is "detached house“. 